\title{
The Chemoenzymatic Total Synthesis of Phellodonic Acid, a Biologically Active and Highly Functionalized Hirsutane Derivative Isolated from the Tasmanian Fungus Phellodon melaleucus
}

\author{
Tristan A. Reekie, ${ }^{\mathrm{A}}$ Kerrie A. B. Austin, ${ }^{\mathrm{A}}$ Martin G. Banwell, ${ }^{\mathrm{A}, \mathrm{B}}$ \\ and Anthony C. Willis ${ }^{\mathrm{A}}$ \\ A Research School of Chemistry, Institute of Advanced Studies, The Australian National University, \\ Canberra, ACT 0200, Australia. \\ ${ }^{B}$ Corresponding author. Email: mgb@rsc.anu.edu.au
}

\begin{abstract}
A total synthesis of the title natural product, $\mathbf{1}$, has been achieved using the cis-1,2-dihydrocatechol 7 as starting material. Compound 7 is readily obtained in large quantity and in an enantiomerically pure form through the whole-cell biotransformation of toluene using the genetically engineered microorganism E. coli JM109 (pDTG601) that overexpresses the enzyme toluene dioxygenase (TDO). Three key chemical steps were employed in the synthesis, the first of which was the microwave-promoted Diels-Alder cycloaddition reaction between diene $\mathbf{8}$ and cyclopent-1-en-2-one to give adduct $\mathbf{9}$. The second key step was the photochemically promoted oxa-di- $\pi$-methane rearrangement of the bicyclo[2.2.2] octenone derivative 15 of 9 to give the epimers 16 and 17, and the third key step was the reductive cleavage of the last pair of compounds so as to afford the linear triquinane 19. Elaboration of compound 19 to target $\mathbf{1}$ followed established procedures. Single-crystal X-ray analyses were carried out on compounds 11 and 19.
\end{abstract}

Manuscript received: 21 November 2007.

Final version: 3 January 2008.

\section{Introduction}

In 1993 Steglich and co-workers reported the isolation of the sesquiterpenoid natural product phellodonic acid (1, Fig. 1) from the fermentations of the fungus Phellodon melaleucus strain 87113 that had been collected in the Hartz Mountains of Tasmania. ${ }^{[1]}$ Its structure was elucidated by spectroscopic methods, most particularly by detailed NMR analysis. The compound exhibits strong inhibitory activities towards various

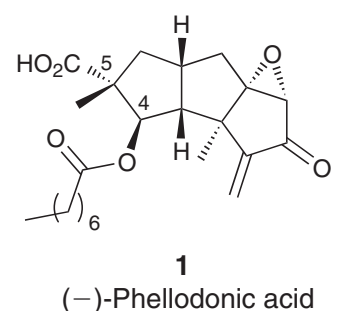

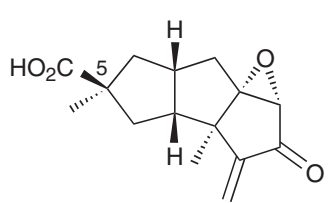

(-)-Complicatic acid

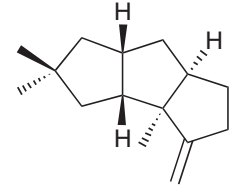

3

$(+)$-Hirsutene
Fig. 1. bacteria, cancer cells, yeasts, and filamentous fungi as well as the alga Chlorella vulgaris. For example, it displays an MIC of $5 \mu \mathrm{g} \mathrm{mL}^{-1}$ against Bacillus subtilis, and an $\mathrm{IC}_{50}$ of $2 \mu \mathrm{g} \mathrm{mL}^{-1}$ against the L1210 cell line. Interestingly, the producing strain is not sensitive to even high concentrations of its own metabolite. It is likely that the source of the abovementioned inhibitory effects is the presence of the carbonyl-conjugated exocyclic methylene within the right-hand ring of compound $\mathbf{1}$, because this motif would be expected to react with thiols such as those found in the cysteine residues of peptides and proteins. As such phellodonic acid displays biological properties similar to those exhibited by other linear-triquinane-type sesquiterpenoids such as complicatic acid (2), ${ }^{[2]}$ hypnophilin, ${ }^{[3-5]}$ pleurotellol, ${ }^{[3,4]}$ and pleurotellic acid. ${ }^{[3,4]}$ All of these compounds are thought to arise, in vivo, through oxidation of the corresponding hydrocarbon natural product hirsutene $(3){ }^{[6]}$

Phellodonic acid (1) represents one of the most heavily oxidized derivatives of hirsutene (3) yet discovered. It differs from the more well known complicatic acid (2) by virtue of possessing the opposite configuration at $\mathrm{C} 5$ and bearing a $\beta$-orientated (1-oxooctyl)oxy side chain at $\mathrm{C} 4$, a structural feature that is also encountered in the related linear-triquinane natural product coriolin B. ${ }^{[7]}$ Thus far, no total synthesis of the title compound has been reported, a surprising situation given derivatives of it bearing alternate $\mathrm{C} 4$ substituents might display selective cytotoxicities. On this basis, and because of our recently completed total synthesis of complicatic acid (2) ${ }^{[8]}$ from a toluene-derived and enantiomerically pure metabolite, ${ }^{\left[{ }^{[9}\right.}$ we sought to adapt our 
earlier work to the preparation of the title compound. Details of the successful outcome of such efforts are reported herein.

Following our earlier studies, ${ }^{[8]}$ the retrosynthetic analysis shown in Fig. 2 was employed to establish the present route to phellodonic acid. Thus, the target compound was considered accessible through appropriate functional group interconversions (FGIs), including cyclopropane ring-cleavage, of the cyclopropannulated triquinane $\mathbf{4}$ that should itself be available through a photochemically promoted oxa-di- $\pi$-methane rearrangement of the cyclopentannulated bicyclo[2.2.2]octenone derivative 5 . This last compound should, in turn, be accessible by a Diels-Alder cycloaddition reaction between cyclopent2-en-1-one (6) and the cyclohexadiene derivative 7, which is itself obtained in multi-gram quantities and in an enantiomerically pure form through the whole-cell mediated cis-1,2dihydroxylation of toluene. ${ }^{[9]}$ Such a sequence of pericyclic and photochemical events was first introduced by Demuth ${ }^{[10]}$ as a means for assembling the linear triquinane ring system and has subsequently been used by various groups for the purposes of assembling hirsutene-type natural products. ${ }^{[8,11]}$

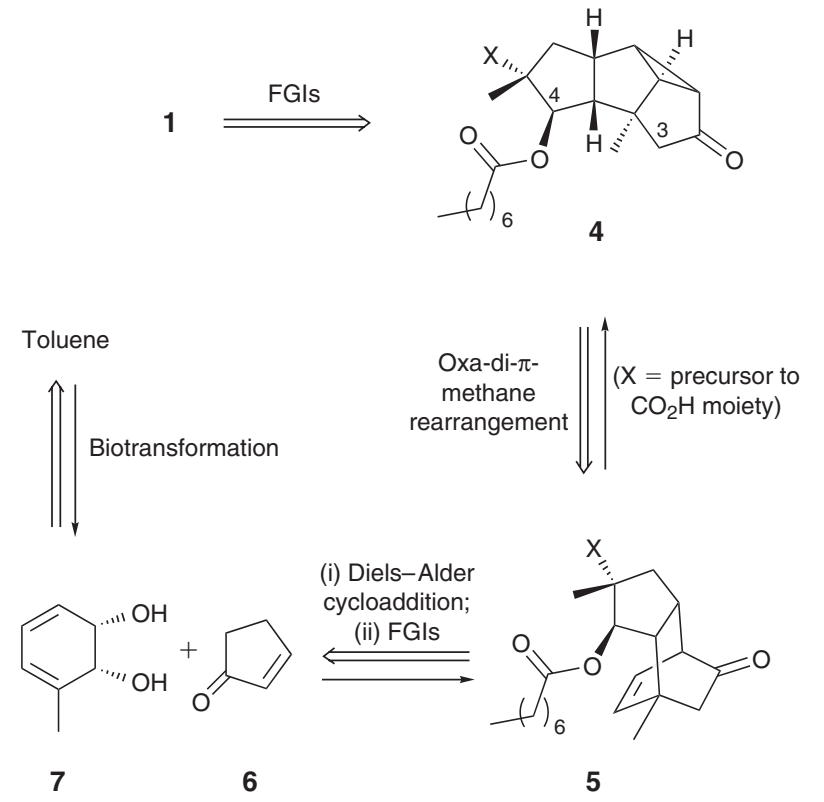

Fig. 2. Retrosynthetic analysis of phellodonic acid (1).

\section{Results and Discussion}

\section{The Diels-Alder Cycloaddition Reaction}

The first stage of the synthesis of phellodonic acid is shown in Scheme 1. It involves the foreshadowed Diels-Alder cycloaddition reaction and leads to the formation of a substrate for the oxa-di- $\pi$-methane rearrangement. Thus, the starting diene 7 was first converted into the corresponding and previously reported $^{[12]}$ acetonide derivative $\mathbf{8}(83 \%)$ under standard conditions. This last compound fails to engage in a thermally-induced Diels-Alder cycloaddition with the dieneophile 6. Furthermore, such cis-1,2-dihydrocatechol derivatives are especially prone to acid-catalyzed rearomatization, which means that Lewis acids cannot be used to promote the desired cycloaddition process. As a result we were ultimately forced to effect this conversion, leading to adduct 9 (73\%), at high pressure (19kbar) in an apparatus that has a relatively small working volume $\left(\sim 13 \mathrm{~mL}\right.$ at STP) and that is difficult to set up and maintain. ${ }^{[8]}$

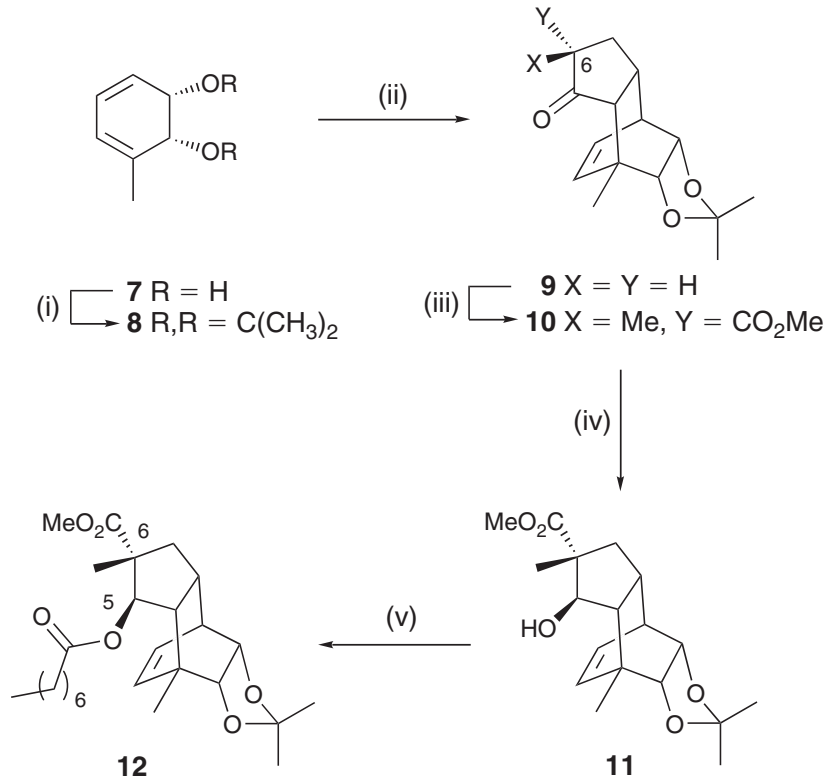

(vi)

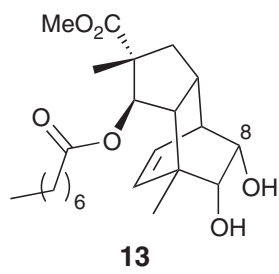

(vii)
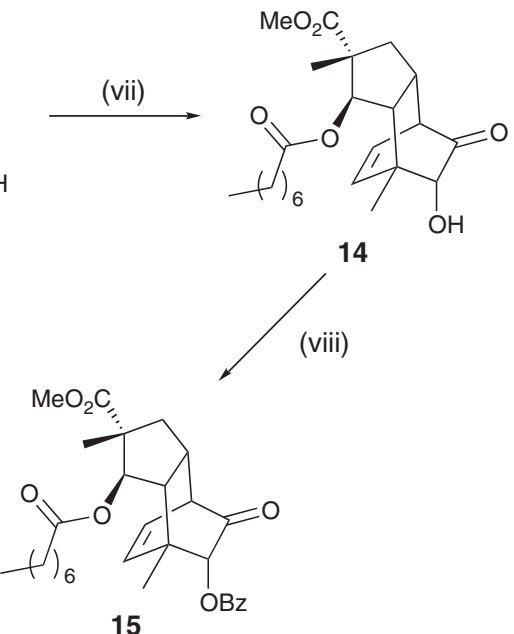

Scheme 1. Reagents and conditions: (i) $\mathrm{Me}_{2} \mathrm{C}(\mathrm{OMe})_{2}, p-\mathrm{TsOH} \cdot \mathrm{H}_{2} \mathrm{O}$ (cat.), $-10^{\circ} \mathrm{C}, 2 \mathrm{~h}$ then $\mathrm{Et}_{3} \mathrm{~N}$ quench; (ii) cyclopent-2-en-1-one $(5 \mathrm{~mol}$ equiv.), microwave irradiation, $200^{\circ} \mathrm{C}, 0.25 \mathrm{~h}$; (iii) first step: LiHMDS ( $1.5 \mathrm{~mol}$ equiv.), THF, $-78^{\circ} \mathrm{C}, 2 \mathrm{~h}$ then $\mathrm{NCCO}_{2} \mathrm{Me}(1.1 \mathrm{~mol}$ equiv. $),-78$ to $18^{\circ} \mathrm{C}, 14 \mathrm{~h}$; second step: $\mathrm{MeI}$ (1.2 mol equiv.), $\mathrm{K}_{2} \mathrm{CO}_{3}$ (1.1 mol equiv.), acetone, $18^{\circ} \mathrm{C}, 24 \mathrm{~h}$; (iv) $\mathrm{CeCl}_{3} \cdot 7 \mathrm{H}_{2} \mathrm{O}$ ( 2 mol equiv.), $\mathrm{NaBH}_{4}$ ( 2 mol equiv.), methanol, 0 to $18^{\circ} \mathrm{C}, \sim 4 \mathrm{~h}$; (v) octanoyl chloride (1.1 mol equiv.), DMAP ( 2.5 mol equiv.), $\mathrm{CH}_{2} \mathrm{Cl}_{2},-78$ to $18^{\circ} \mathrm{C}, \sim 20 \mathrm{~h}$; (vi) DOWEX-50 resin (excess of activated material), methanol- $\mathrm{H}_{2} \mathrm{O}, 110^{\circ} \mathrm{C}, 3$ to 4 days; (vii) 4-AcNHTEMPO (2.2 mol equiv.), $p$-TsOH$\cdot \mathrm{H}_{2} \mathrm{O}$ ( $2.2 \mathrm{~mol}$ equiv.), $\mathrm{CH}_{2} \mathrm{Cl}_{2}$, 0 to $18^{\circ} \mathrm{C}, 7 \mathrm{~h}$; (viii) $\mathrm{C}_{6} \mathrm{H}_{5} \mathrm{COCl}$ (3.1 mol equiv.), DMAP (4.1 mol equiv.), $\mathrm{CH}_{2} \mathrm{Cl}_{2}, 0$ to $18^{\circ} \mathrm{C}, \sim 20 \mathrm{~h}$.

The emergence of commercially available and purpose-built microwave reactors has provided a capacity for promoting a wide range of processes including Diels-Alder cycloaddition reactions. ${ }^{[13]}$ Accordingly, various proportions of compounds 6 and $\mathbf{8}$ were subjected, either neat or as solutions in solvents such as dichloromethane, chlorobenzene, or $N, N$-dimethylformamide (DMF), to microwave irradiation. Parameters such as reaction 
temperature, pressure, and time were varied in an effort to maximize the yield of the target adduct 9. Under the best conditions identified so far, it has been established that when a mixture of one molar equivalent of diene $\mathbf{8}$ and five molar equivalents of dienophile 6 was heated (neat) at $200^{\circ} \mathrm{C}$ for $0.25 \mathrm{~h}$ using a reactor supplying $\sim 200 \mathrm{~W}$ of power then a $70 \%$ yield of compound 9 could be obtained. This adduct was accompanied by quantities of the previously observed and chromatographically separable syn-isomer of compound $9(7 \%)$ as well as a Diels-Alder dimer of diene $8(19 \%)$. Because this type of outcome compares very favourably with the one observed ${ }^{[8]}$ on using high pressure to effect the same conversion, the microwave-promoted conversion $\mathbf{6}+\mathbf{8} \rightarrow \mathbf{9}$ is now the preferred one in these laboratories.

Deprotonation of ketone 9 with LiHMDS and treatment of the ensuing enolate with Mander's reagent ${ }^{[14]}$ afforded a mixture of the expected C6-carbomethoxylated compound and various tautomers ( $84 \%$ combined yield). Attempts to effect C6-methylation of this material by treating it, successively, with $\mathrm{NaH}$ and iodomethane failed to deliver the previously reported keto ester 10. However, by simply carrying out the methylation step with the same electrophile but using potassium carbonate as base and acetone as solvent the required compound (10) was produced in $98 \%$ yield. The stereochemistry shown at C6 in this product, which is as required at the equivalent centre in target $\mathbf{1}$, was not rigorously proven at this point but is the one expected based on the likely trajectory of the approach of iodomethane to the anion derived from the intermediate $\beta$-keto-ester. Reaction of ketone $\mathbf{1 0}$ with a combination of cerium(III) chloride and sodium borohydride (Luche reduction conditions) ${ }^{[15]}$ proceeded smoothly to give, in $73 \%$ yield, alcohol 11 as a white, crystalline solid. The structure of this compound follows from a single-crystal X-ray analysis and the derived ORTEP diagram is shown in Fig. 3. Interestingly, when ketone $\mathbf{1 0}$ is simply treated with sodium borohydride (no added $\mathrm{CeCl}_{3}$ ) then a chromatographically separable mixture of compound 11 (23\%) and its C5-epimer (45\%) is obtained. Clearly, then, the presence of the cerium salt is having a significant impact on the stereoselectivity of the reduction process. One possible explanation for this effect involves simultaneous coordination of the cerium(III) cation to the carbonyl oxygens of both the ester and the ketone with the cerium-bound hydride then attacking the ketone carbon from the same face as the ester and thus establishing a trans-relationship between the ester and alcohol moieties in the product. Some support for this argument follows from the observation that the $\mathrm{CeCl}_{3} / \mathrm{NaBH}_{4}$-mediated reduction of the C6-epimer of compound $\mathbf{1 0}$ leads, in $91 \%$ yield, to that product where there is also a trans-relationship between the hydroxy and ester groups. ${ }^{[8]}$

The reaction sequence just described has allowed for the fully controlled introduction of the functionalities and stereochemistries required at $\mathrm{C} 4$ and $\mathrm{C} 5$ in the left-hand ring of phellodonic acid. The question that now arose was how the newly introduced hydroxy group might be carried through the reaction sequence leading to target $\mathbf{1}$. In the event, we chose to install the octanoyloxy moiety at this stage on the basis that if this group survived the remaining steps of the reaction sequence then this would provide the most direct way of installing the side-chain of phellodonic acid. On this basis, alcohol 11 was treated with 4- $(N$, $N$-dimethylamino)pyridine (DMAP) and then octanoyl chloride at $-78^{\circ} \mathrm{C}$ and in this manner the required ester 12 was obtained in $81 \%$ yield. The acetonide unit within the latter compound was hydrolyzed by treating a methanol-water solution of it with freshly activated DOWEX -50 resin at $\sim 110^{\circ} \mathrm{C}$ for $3-4$ days. In this way the required diol $\mathbf{1 3}$ was obtained as a clear, colourless

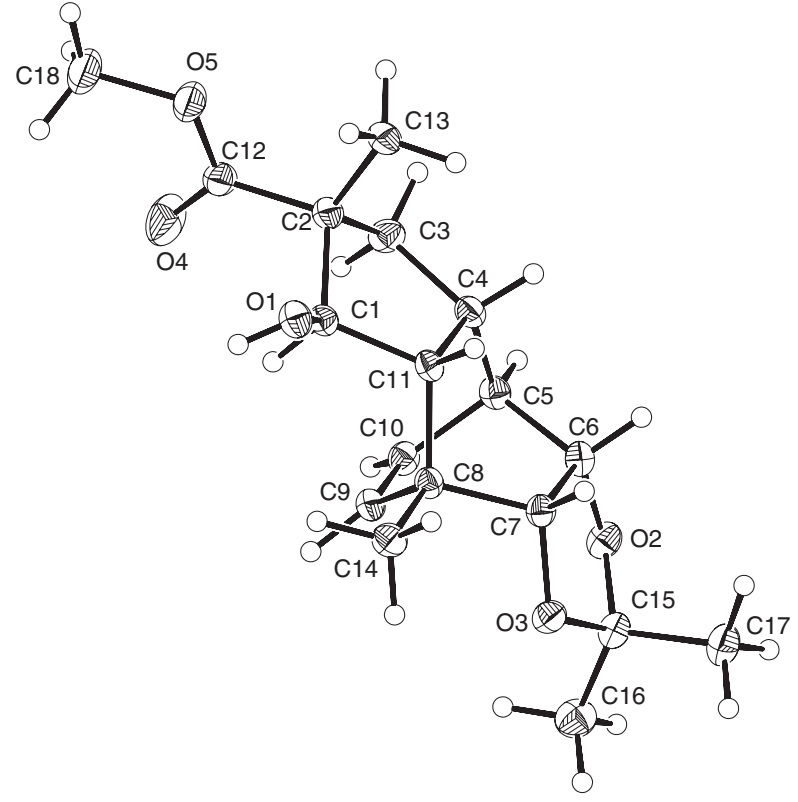

Fig. 3. ORTEP diagram derived from the single-crystal X-ray analysis of compound 11 with labelling of selected atoms. Anisotropic displacement ellipsoids display $30 \%$ probability levels. Hydrogen atoms are drawn as circles with small radii. Only the major sites for the disordered $\mathrm{H}$ atoms on C18 are drawn.

oil in 78\% yield. These types of rather vigorous hydrolysis conditions are frequently required ${ }^{[8]}$ to cleave acetonides that are annulated in this manner to the bicyclo[2.2.2] octanyl framework. The selective oxidation of the C8-hydroxy group within diol 13 was readily accomplished using the oxammonium salt derived from the $p$-toluenesulfonic acid-mediated disproportionation of 4-acetamido-TEMPO ${ }^{[16]}$ and in this manner the acyloin 14 was obtained in 94\% yield. The observed selectivity arises from the sterically demanding nature of the oxidant that ensures only the hydroxy group within substrate $\mathbf{1 3}$ that is remote from the bridgehead methyl group is converted into the corresponding ketone. As the final step in the synthesis of the substrate required for the foreshadowed oxa-di- $\pi$-methane rearrangement, ${ }^{[17]}$ the hydroxy moiety within acyloin 14 was converted, under standard conditions, into the corresponding benzoate $\mathbf{1 5}(81 \%)$. A major motivation for effecting this last conversion is that acyloins such as $\mathbf{1 4}$ are rather prone to dimerization through a two-step process that involves initial reaction of the hydroxy group of one molecule with the ketone carbonyl of another followed by an intramolecular variation of this same process which leads to a bis-lactol. ${ }^{[18]}$ Not only does the introduction of the benzoate group prevent this dimerization process but it also provides a means (see below) for readily deleting this remaining hydroxy group that is not required in the final target.

\section{The Oxa-di- $\pi$-methane Rearrangement Reaction}

With the proposed substrate, 15, required for the oxa-di- $\pi$ methane rearrangement reaction in hand this photochemical step could be investigated. Initial efforts (Scheme 2) focussed on applying previously employed conditions to effect the rearrangement that involved irradiating a water-cooled $\left(5-10^{\circ} \mathrm{C}\right)$ acetone solution of compound $\mathbf{1 5}$ and acetophenone contained in a Pyrex vessel with the light from an externally located Phillips $125 \mathrm{~W}$ HPL-N lamp that was filtered through an aqueous solution of sodium bromide and lead(II) nitrate in water. ${ }^{[8]}$ Under 


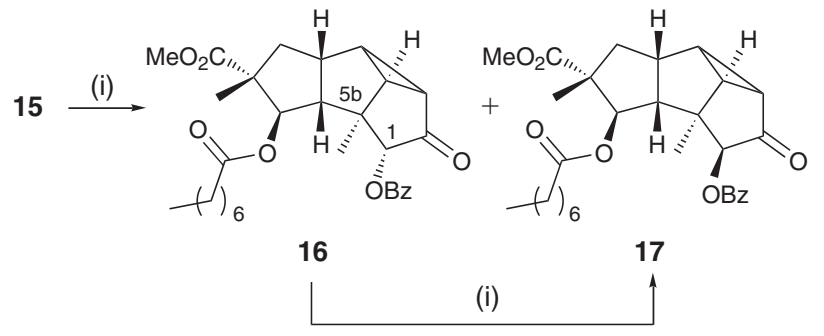

Scheme 2. Reagents and conditions: (i) acetophenone (3 mol equiv.), acetone, $h v, 3 \mathrm{~h}$.

such conditions the two chromatographically separable photoproducts obtained were the triquinane $16(42 \%)$ and its epimer 17 (40\%). These compounds were accompanied by $16 \%$ of the starting material. Interestingly, and in contrast to the situation observed in our work directed towards the synthesis of complicatic acid, ${ }^{[8]}$ no cyclobutanone-containing products arising from a photo-induced 1,3-acyl-migration process were observed. In a control experiment, a purified sample of compound $\mathbf{1 6}$ was resubjected to the irradiation conditions defined above and in this manner epimer 17 was obtained in $96 \%$ yield. The relief of steric compression between the adjacent and syn-related C5b-methyl and C1-benzoyloxy groups within compound $\mathbf{1 6}$ presumably drives the photoenolization or $\alpha$-cleavage process that is probably involved in this epimerization reaction. The presence of one or other or both of epimers $\mathbf{1 6}$ and $\mathbf{1 7}$ in any given reaction mixture was readily discerned by ${ }^{1} \mathrm{H}$ NMR spectroscopic analysis because the $\mathrm{C} 1$-oxymethine proton resonates at $\delta 4.95$ in the former compound and at $\delta 5.35$ in the latter. The deshielded nature of the latter resonance is attributed to the orthogonal relationship between the $\mathrm{C} 1-\mathrm{H}$ bond and the plane defined by the four atoms of the flanking ketone residue. Certainly, similar variations in chemical shift are seen in various epimerically related $\alpha$-oxygenated and cyclic ketones. ${ }^{[19]}$

An improved method for effecting the conversion $\mathbf{1 5} \rightarrow \mathbf{1 6}+$ 17 involved using a quartz immersion-well photoreactor equipped with a Pyrex filter sleeve and a Hanovia $450 \mathrm{~W}$ medium-pressure quartz mercury-vapour lamp and allowing the reaction to run without external cooling. Under such conditions the photoisomerization reaction could be driven to completion and a $\sim 1: 10$ mixture of compounds $\mathbf{1 6}$ and $\mathbf{1 7}$ was obtained in $90 \%$ combined yield. Using the same irradiation conditions it was also established that compound 16, the primary product of the oxa-di- $\pi$-methane rearrangement process, could be converted into isomer 17 over just $0.5 \mathrm{~h}$ and in $97 \%$ yield.

\section{Conversion of the Photo-Arrangement Products $\mathbf{1 6}$ and $\mathbf{1 7}$} into Phellodonic Acid (1)

The completion of the synthesis of phellodonic acid (1) required, amongst other things, the reductive cleavage of the cyclopropyl and benzoyloxy groups within compounds $\mathbf{1 6}$ and $\mathbf{1 7}$ In principle, both of these processes could be accomplished simultaneously, and within the framework of either substrate, using samarium(II) iodide which is known to cleave carbonylconjugated three-membered rings and acyloxy groups adjacent to ketones. ${ }^{[20]}$ However, our earlier work on the development of a synthesis of complicatic acid revealed that while acyloxy group removal could be accomplished rather readily with this reagent, when an excess of it was used in order to also cleave the cyclopropane ring then unwanted $\mathrm{C}-\mathrm{C}$ bond-forming events
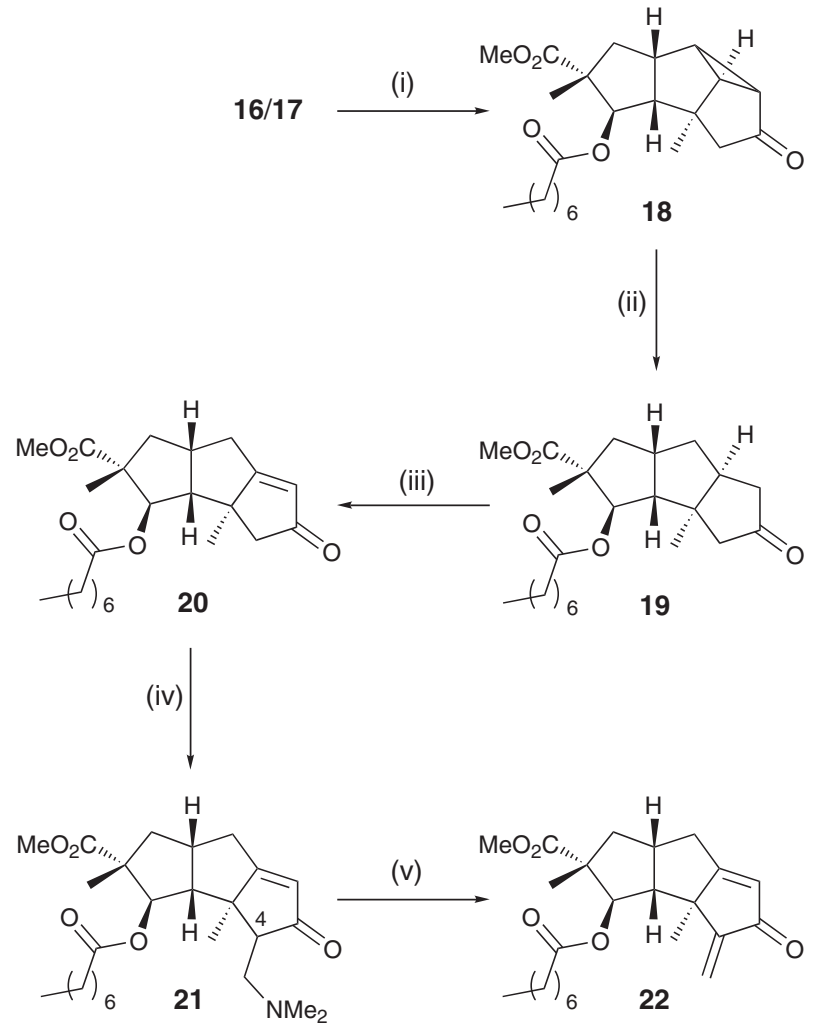

(vi)

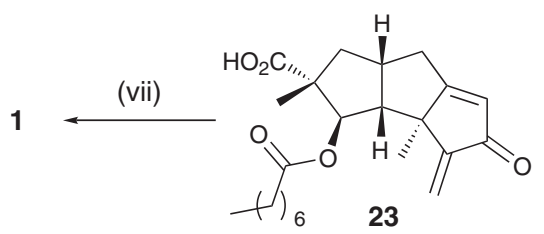

Scheme 3. Reagents and conditions: (i) $\mathrm{SmI}_{2}$ (2.2 mol equiv.) THF-methanol, -78 to $18^{\circ} \mathrm{C}, \sim 0.25 \mathrm{~h}$; (ii) $n$-Bu $3 \mathrm{SnH}$ ( 6 mol equiv.), AIBN (cat.), $\mathrm{C}_{6} \mathrm{H}_{6}, 80^{\circ} \mathrm{C}, 4.5 \mathrm{~h}$; (iii) $\mathrm{IBX}\left(3.9 \mathrm{~mol}\right.$ equiv.), $p$ - $\mathrm{TsOH} \cdot \mathrm{H}_{2} \mathrm{O}$ (cat.), toluene with DMSO, $55^{\circ} \mathrm{C}, 96 \mathrm{~h}$; (iv) LiHMDS (1.1 mol equiv.), THF, $-78^{\circ} \mathrm{C}, 1 \mathrm{~h}$ then $\mathrm{H}_{2} \mathrm{C}=\mathrm{NMe}_{2} \mathrm{I}(2.9$ mol equiv. $),-78$ to $18^{\circ} \mathrm{C}, 16 \mathrm{~h}$; (v) first step: $\mathrm{MeI}$ ( $12 \mathrm{~mol}$ equiv.), $\mathrm{Et}_{2} \mathrm{O}-\mathrm{CH}_{2} \mathrm{Cl}_{2}, 18^{\circ} \mathrm{C}, 16 \mathrm{~h}$; second step: basic alumina (large excess), $\mathrm{CH}_{2} \mathrm{Cl}_{2}, 18^{\circ} \mathrm{C}, 0.5 \mathrm{~h}$; (vi) $\mathrm{AlBr}_{3}$ (6 mol equiv.), tetrahydrothiophene, $18^{\circ} \mathrm{C}, 0.5 \mathrm{~h}$; (vii) $\mathrm{H}_{2} \mathrm{O}_{2}$ ( 3 mol equiv.), $\mathrm{NaHCO}_{3}$ (6.66 mol equiv.), methanol- $\mathrm{H}_{2} \mathrm{O}, 0$ to $18^{\circ} \mathrm{C}, 1.25 \mathrm{~h}$.

occurred ${ }^{[8]}$ Accordingly, in this earlier work, a two-step reduction pathway that involved the use of $\mathrm{SmI}_{2}$ then $n$-Bu $\mathrm{Bu}_{3} \mathrm{SnH}$ was developed so as to maximize the yield of the desired material. On this basis, the same approach was taken in the present synthesis. Thus, a THF-methanol solution of compound $\mathbf{1 6}$ or $\mathbf{1 7}$, or a mixture thereof, was cooled to $-78^{\circ} \mathrm{C}$ and then treated with 2.2 mol equivalents of $\mathrm{SmI}_{2}$. The reaction mixture was then quenched with $\mathrm{K}_{2} \mathrm{CO}_{3}$ (Scheme 3). The usual workup provided the expected ketone 18 in $96 \%$ yield. Following conditions described by Singh et al. ${ }^{[1 \mathrm{a}]}$ compound $\mathbf{1 8}$ was treated with tri- $n$-butyltin hydride and azobisisobutyronitrile (AIBN) in refluxing benzene for $4.5 \mathrm{~h}$ and in this manner the crystalline triquinane 19 was obtained in $83 \%$ yield at $95 \%$ conversion. A single-crystal X-ray analysis was undertaken on this material but the structure proved difficult to refine because of disorder 


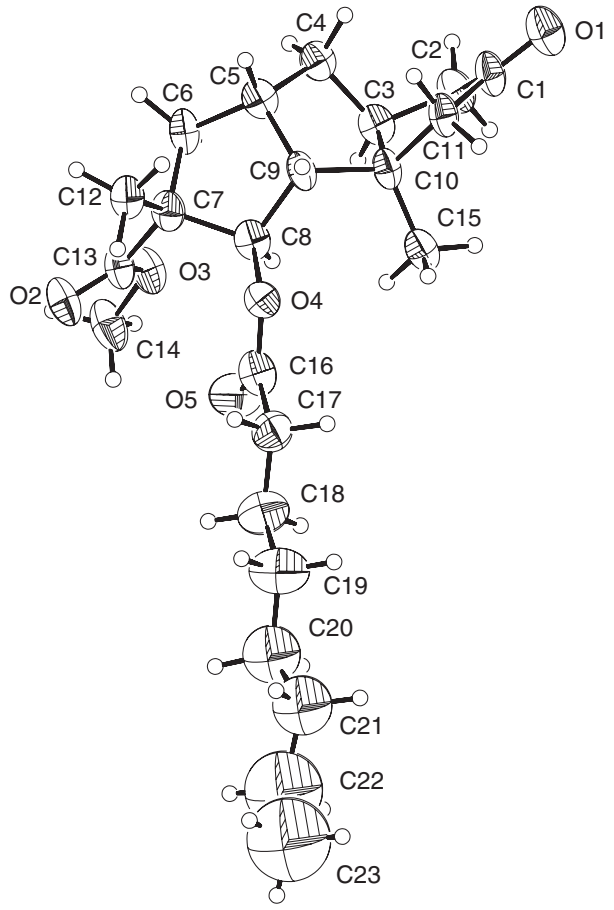

Fig. 4. ORTEP diagram derived from the single-crystal X-ray analysis of compound 19 with labelling of selected atoms. Anisotropic displacement ellipsoids display $30 \%$ probability levels. Hydrogen atoms are drawn as circles with small radii. Only the major sites for the disordered atoms are drawn.

of the terminal atom of the octanoyl side-chain and the presence of a disordered solvate molecule. As a result, the $R$ factor associated with dataset presented in the Experimental section is rather high $(11 \%)$. The ORTEP plot presented in Fig. 4 shows one conformation only of the last three carbons (and associated hydrogens).

Reaction of compound 19 with $o$-iodoxybenzoic acid (IBX) in the presence of stoichiometric quantities of $p$-toluenesulfonic acid $^{[21]}$ effected the direct dehydrogenation of this substrate and afforded the enone $\mathbf{2 0}$ in $81 \%$ yield. The enolate anion derived from deprotonation of the last compound was treated with Eschenmoser's salt ${ }^{[22]}$ to give the tertiary amine 21 (75\%). The methiodide salt derived by reacting compound $\mathbf{2 1}$ with iodomethane was subjected to Hoffmann elimination using basic alumina and by such means the dienone 22 was obtained in $80 \%$ yield. ${ }^{[23]}$

The acquisition of compound $\mathbf{2 2}$ meant that just two further synthetic manipulations were required to complete the synthesis of target $\mathbf{1}$, namely cleavage of the methyl ester to reveal the $\mathrm{C} 5$-acid function and introduction of the epoxide ring. Of course, a careful selection of the reaction conditions for achieving such ends was required because of the potential for simultaneous cleavage of the octanoyl side-chain. Furthermore, given the sensitivity of the epoxide ring, its introduction was left until the final step of the synthesis. Initial attempts to cleave the ester unit within triquinane 22 using LiI in DMF at $\sim 150^{\circ} \mathrm{C}$, conditions which had been exploited successfully in our recently reported synthesis of complicatic acid, ${ }^{[8]}$ failed to deliver any useful outcome. In contrast, upon using a modification of a procedure defined by Greene et al. ${ }^{[24]}$ that involved treating the ester with $\mathrm{AlBr}_{3}$ in tetrahydrothiophene at $18^{\circ} \mathrm{C}$, the target acid $\mathbf{2 3}$ was obtained in $89 \%$ yield after an acidic workup. The nucleophilic
Table 1. A comparison of the $70 \mathrm{eV}$ electron-impact-induced mass spectrometric fragmentation patterns of the synthetically and naturally derived samples of phellodonic acid (1)

\begin{tabular}{lccc}
\hline & $\begin{array}{c}\text { Synthetically derived 1 } \\
\text { Percentage of } \\
\text { base peak }^{\mathrm{B}}\end{array}$ & $m / z$ & $\begin{array}{c}\text { Naturally derived } \mathbf{1}^{\mathrm{C}} \\
\text { Percentage of } \\
\text { base peak }^{\mathrm{B}}\end{array}$ \\
\hline $404\left(\mathrm{M}^{+\bullet}\right)$ & 1 & 404 & 1 \\
262 & 3 & 262 & 3 \\
261 & 12 & 261 & 12 \\
260 & 63 & 260 & 62 \\
245 & 7 & 245 & 5 \\
232 & 9 & 232 & 9 \\
231 & 10 & 231 & 8 \\
216 & 20 & 216 & 20 \\
215 & 100 & 215 & 100 \\
214 & 12 & 214 & 7 \\
204 & 7 & 204 & 25 \\
203 & 29 & 203 & 13 \\
127 & 25 & 127 & 61 \\
57 & 89 & 57 & \\
\hline
\end{tabular}

${ }^{A}$ Additional fragment ions are observed in the mass spectrum of the synthetic material at $m / z 246(8 \%), 170$ (23), 141 (23), 77 (32) and 69 (33) and 55 (48).

${ }^{\mathrm{B}}$ Intensities have been rounded to the nearest percentage point.

${ }^{\mathrm{C}}$ Data derived from ref. [1].

epoxidation of this last compound was best carried out at $0^{\circ} \mathrm{C}$ using $30 \% \mathrm{w} / \mathrm{v}$ aqueous hydrogen peroxide in the presence of sodium bicarbonate and by such means phellodonic acid was finally obtained as a light-yellow oil, albeit in only $48 \%$ yield. While various attempts to improve the efficiency of this last step have been unsuccessful, this outcome is consistent with those observed in the nucleophilic epoxidation of the precursor to complicatic acid. ${ }^{[8]}$ Despite these difficulties, sufficient quantities of compound $\mathbf{1}$ could be obtained by such means to allow for full characterization of this material.

Comparison of the Spectroscopic Data Sets Arising from Synthetically- and Naturally-Derived Phellodonic Acid (1)

The spectroscopic data obtained for synthetically derived phellodonic acid were fully consistent with the assigned structure and in excellent agreement with those reported for the natural product. ${ }^{[1]}$ For example, the specific rotations of the two materials were of the same sign and very similar magnitude $\left\{[\alpha]_{\mathrm{D}}\right.$ (synthetic) $-120\left(c 0.2, \mathrm{CHCl}_{3}\right) v \cdot[\alpha]_{\mathrm{D}}$ (natural $)^{[1]}-114(c 1.67$, $\left.\left.\mathrm{CHCl}_{3}\right)\right\}$. Furthermore, the $70 \mathrm{eV}$ electron-impact-induced mass spectrometric fragmentation patterns of the two materials were essentially identical (Table 1) and accurate mass measurements on the molecular-associated ions, $(\mathrm{M}+\mathrm{H})^{+}$and $(\mathrm{M}+\mathrm{Na})^{+}$, observed in the electrospray (ES)-induced mass spectrum established that the synthetic material was of the expected molecular composition, i.e., $\mathrm{C}_{23} \mathrm{H}_{32} \mathrm{O}_{6}$. The infrared spectroscopic data derived from each sample were also in good agreement with the key absorption bands appearing at 3507 (- $\mathrm{COOH}$ stretch), 1732 ( - COO - stretch), and $1638(\mathrm{C}=\mathrm{C}$ stretch $) \mathrm{cm}^{-1}$ observed for the synthetically-derived material.

The ${ }^{13} \mathrm{C}$ NMR spectroscopic data obtained, in $\mathrm{C}_{6} \mathrm{D}_{6}$ at $125 \mathrm{MHz}$, on synthetic phellodonic acid (1) were in good agreement with those recorded on the naturally derived material in the same solvent at $100 \mathrm{MHz} .{ }^{[1]}$ A comparison of the two datasets is presented in Table 2 and this reveals that the only substantial discrepancy between them involves the signal attributable to 
Table 2. Comparison of the ${ }^{13} \mathrm{C}$ NMR spectroscopic data recorded for synthetically- and naturally-derived samples of phellodonic acid (1)

\begin{tabular}{lccc}
\hline & \multicolumn{2}{c}{$\delta_{\mathrm{C}}$} & \\
Synthetic 1 $^{\mathrm{A}}$ & Natural 1 $^{\mathrm{B}}$ & Synthetic 1 $^{\mathrm{A}}$ & Natural 1 $^{\mathrm{B}}$ \\
\hline 197.2 & 196.8 & 36.5 & 35.9 \\
$184.9^{\mathrm{C}}$ & 181.5 & 34.9 & 34.3 \\
173.2 & 172.7 & 32.6 & 32.0 \\
153.5 & 152.9 & 30.8 & 30.2 \\
121.5 & 121.0 & $29.8(9)$ & 29.3 \\
78.3 & 77.8 & $29.8(5)$ & 29.2 \\
76.4 & 75.9 & 25.9 & 25.3 \\
61.4 & 60.8 & 23.6 & 23.0 \\
$54.7^{\mathrm{D}}$ & 54.2 & 18.1 & 17.5 \\
& 54.1 & 17.4 & 16.8 \\
46.7 & 46.2 & 14.9 & 14.3 \\
44.2 & 43.7 & & \\
\hline
\end{tabular}

${ }^{A}$ Data recorded in $\mathrm{C}_{6} \mathrm{D}_{6}$ at $125 \mathrm{MHz}$, spectrum referenced to central peak $(\delta 128.1)$ of the signals due to $\mathrm{C}_{6} \mathrm{D}_{6}$.

${ }^{\mathrm{B}}$ Data extracted from ref. [1] (recorded in $\mathrm{C}_{6} \mathrm{D}_{6}$ at $105 \mathrm{MHz}$, spectrum referenced to added TMS)

${ }^{\mathrm{C}}$ This signal could not be found in the original spectrum but was detected in a separate experiment using a reduced sweep width.

DTwo-dimensional NMR experiments have established that this signal arises from the overlapping resonances due to two distinct carbon atoms within $\mathbf{1}$

the carboxylic acid carbon (C5). This appears at $\delta 181.5$ in the spectrum of the natural product but could not be discerned in the initially generated spectrum of the synthetic material. In order to be able to observe this signal, a separate experiment was undertaken that involved a reduced sweep width and that was focussed on the relevant region of the spectrum. As a consequence of this, as well as the sensitivity of carboxylic acid carbon resonances to solvent and $\mathrm{pH}$ effects, the difference in chemical shifts between the C5 signals is not considered significant. The small but near constant variation $(\Delta \delta 0.4-0.6)$ between the chemical shifts of the corresponding signals in the two datasets can be attributed to the two distinct methods used to reference each spectrum (see footnotes A and B, Table 2).

A comparison of the initially obtained $300 \mathrm{MHz}{ }^{1} \mathrm{H}$ NMR spectrum of synthetic phellodonoic acid with the corresponding $400 \mathrm{MHz}$ spectrum of the natural product, as kindly provided to us by Professor Steglich (LMU, Munich), revealed that these were in excellent agreement with one another. Ultimately, the $800 \mathrm{MHz}{ }^{1} \mathrm{H}$ NMR spectrum of synthetic phellodonic acid was recorded and the data derived from this are listed in Table 3 alongside the analogous data originally reported for the natural product. ${ }^{[1]}$ The agreement between the two sets of data is excellent with the only significant difference between the two arising from the greater resolution attained during the recording of the spectrum of the synthetic material. In particular, the four-proton envelope that appears in the $\delta 2.18-1.90$ range in the $400 \mathrm{MHz}$ ${ }^{1} \mathrm{H}$ NMR spectrum of the natural product is resolved into four separate, one-proton envelopes in the corresponding spectrum of the synthetic material.

From the foregoing, it seems clear that the naturally- and synthetically-derived samples of phellodonic acid (1) are one and the same compound. On this basis, and given the well-defined nature of the 17-step synthetic sequence described herein, it is reasonable to conclude that the structure originally assigned ${ }^{[1]}$ to the title natural product is correct.
Table 3. Comparison of the ${ }^{1} \mathrm{H}$ NMR spectroscopic data recorded for synthetically- and naturally-derived samples of phellodonic acid (1)

\begin{tabular}{|c|c|}
\hline \multicolumn{2}{|c|}{$\delta_{\mathrm{H}}$} \\
\hline Synthetic $\mathbf{1}^{\mathrm{A}}$ & Natural $\mathbf{1}^{\mathrm{B}}$ \\
\hline $6.08(\mathrm{~s}, 1 \mathrm{H})$ & $6.05(\mathrm{~s}, 1 \mathrm{H})$ \\
\hline $5.83(\mathrm{~d}, J 7.2,1 \mathrm{H})$ & $5.80(\mathrm{~d}, J 7.2,1 \mathrm{H})$ \\
\hline $5.35($ broad s, 1H) & $5.35($ broad s, $1 \mathrm{H})$ \\
\hline $3.45(\mathrm{~s}, 1 \mathrm{H})$ & $3.43($ broad s, $1 \mathrm{H})$ \\
\hline $2.87(\mathrm{~m}, 1 \mathrm{H})$ & $2.87(\mathrm{~m}, 1 \mathrm{H})$ \\
\hline $2.36-2.22(\mathrm{~m}, 3 \mathrm{H})$ & $2.32-2.19(\mathrm{~m}, 3 \mathrm{H})$ \\
\hline $2.15(\mathrm{~m}, 1 \mathrm{H})$ & $2.18-1.90(\mathrm{~m}, 4 \mathrm{H})$ \\
\hline \multicolumn{2}{|l|}{$2.10(\mathrm{~m}, 1 \mathrm{H})$} \\
\hline \multicolumn{2}{|l|}{$2.05(\mathrm{~m}, 1 \mathrm{H})$} \\
\hline \multicolumn{2}{|l|}{$1.64-1.55(\mathrm{~m}, 2 \mathrm{H})$} \\
\hline $1.41(\mathrm{~s}, 3 \mathrm{H})$ & $1.41(\mathrm{~s}, 3 \mathrm{H})$ \\
\hline $1.34-1.22($ complex m, 11H) & $1.31-1.14(\mathrm{~m}, 11 \mathrm{H})$ \\
\hline $0.88(\mathrm{t}, J 6.5,3 \mathrm{H})$ & $0.86(\mathrm{t}, J 6.5,3 \mathrm{H})$ \\
\hline
\end{tabular}

${ }^{\mathrm{A}}$ Data recorded in $\mathrm{CDCl}_{3}$ at $800 \mathrm{MHz}$, spectrum referenced to peak arising from residual $\mathrm{CHCl}_{3}(\delta 7.26)$.

${ }^{\mathrm{B}}$ Data extracted from ref. [1] (recorded in $\mathrm{CDCl}_{3}$ at $400 \mathrm{MHz}$, spectrum referenced to added TMS).

\section{Conclusions}

The first total synthesis of phellodonic acid has been achieved and this proceeds in a fully stereocontrolled fashion. The present study, particularly when considered in conjunction with our earlier work, ${ }^{[8,9 b]}$ highlights the synthetic utility of the $c i s-1,2-$ dihydrocatehols such as $\mathbf{7}$ for the construction of sesquiterpenoid natural products. Furthermore, given that its enantiomer, ent7 , is also readily available, ${ }^{[25]}$ this work provides a means for establishing a total synthesis of ent-phellodonic acid as well.

As we have noted previously, ${ }^{[8]}$ it is worth reflecting on the rather remarkable role that the methyl group of toluene plays in this synthesis. First of all, this seemingly innocuous group controls the regio-, stereo-, and enantio-selectivity of the TDOmediated dihydroxylation of toluene to give metabolite 7 . This same group then controls the regio-selectivity of the DielsAlder cycloaddition reaction, the oxidation reaction that leads to the acyloin 14, and the IBX-mediated process that leads to the enone $\mathbf{2 0}$.

\section{Experimental}

\section{General Experimental Procedures}

Melting points were measured on either a Stanford Research Systems Optimelt automated melting point system or a Reichert hot-stage microscope apparatus and are uncorrected. Proton $\left({ }^{1} \mathrm{H}\right)$ and carbon $\left({ }^{13} \mathrm{C}\right)$ NMR spectra were recorded on a Varian Gemini $300 \mathrm{MHz}$ or Bruker $800 \mathrm{MHz}$ spectrometer. Unless otherwise specified, spectra were acquired at $20^{\circ} \mathrm{C}$ in deuterochloroform $\left(\mathrm{CDCl}_{3}\right)$ that had been filtered through basic alumina immediately before use. Chemical shifts are recorded as $\delta$ values in parts per million $(\mathrm{ppm})$. Infrared spectra $\left(v_{\max }\right)$ were recorded on a Perkin-Elmer 1800 series FTIR spectrometer and samples were analyzed as $\mathrm{KBr}$ disks (for solids) or as thin films on $\mathrm{KBr}$ plates (for oils). Low-resolution mass spectra were recorded on a Micromass-Waters LC-ZMD single quadrupole liquid chromatograph-MS or a VG Quattro II triple 
quadrupole MS instrument using electron impact techniques. High-resolution mass spectra were recorded on an AUTOSPEC instrument. Flash chromatographic separations were carried out using the protocols defined by Still et al. ${ }^{[26]}$ Dichloromethane (DCM) and acetonitrile were distilled from calcium hydride while THF was distilled, under nitrogen, from sodium benzophenone ketyl. Toluene was distilled from chips of sodium metal. Where necessary, reactions were performed under a nitrogen or argon atmosphere.

\section{Synthetic Studies}

(3aR,7aS)-3a,7a-Dihydro-2,2,4-trimethyl-1,3benzodioxole $(\boldsymbol{8})$

Acetonide 8 was prepared from diol $7^{*}$ using previously described ${ }^{[12]}$ protocols. The spectroscopic data derived from compound 8 (83\%) matched those reported earlier. ${ }^{[12]}$

(3aR,4R,4aR,7aR,8S, 8aS)-3a,4,4a,6,7,7a,8,8a-

Octahydro-2,2,4-trimethyl-4,8-etheno-5H-indeno [5,6-d]-1,3-dioxol-5-one (9)

Method A: The title compound was prepared, in $73 \%$ yield, from acetonide $\mathbf{8}$ and cyclopent-2-en-1-one under high pressure (19 kbar) using previously described protocols. ${ }^{[8]}$ The spectroscopic data derived from this material were identical, in all respects, with those reported earlier. ${ }^{[8]}$

Method B: A solution of acetonide $8(1.62 \mathrm{~g}, 9.75 \mathrm{mmol})$ in cyclopent-2-en-1-one $(4.08 \mathrm{~mL}, 48.7 \mathrm{mmol})$ was irradiated in a CEM Discover microwave reactor at $200^{\circ} \mathrm{C}$ for $0.25 \mathrm{~h}$. The resulting yellow solution was cooled to $18^{\circ} \mathrm{C}$ then subjected to flash chromatography (silica, hexane $\rightarrow 1 / 4 \mathrm{v} / \mathrm{v}$ ethyl acetate/hexane gradient elution) and two fractions, A and B, thereby obtained.

Concentration of fraction $\mathrm{A}\left(R_{\mathrm{F}} \quad 0.2\right.$ in $3 / 7 \mathrm{v} / \mathrm{v}$ ethyl acetate/hexane) afforded the title compound $9(1.69 \mathrm{~g}, 70 \%)$ as white needles, $\mathrm{mp} 78-80^{\circ} \mathrm{C}\left(\right.$ (lit. $\left.^{[8]} 79-89^{\circ} \mathrm{C}\right)$. The spectroscopic data derived from this material were identical, in all respects, with those reported earlier. ${ }^{[8]}$

Concentration of fraction $\mathrm{B}\left(R_{\mathrm{F}} \quad 0.4\right.$ in $3 / 7 \mathrm{v} / \mathrm{v}$ ethyl acetate/hexane) afforded a yellow oil that was subjected to further flash chromatography (silica, hexane $\rightarrow 5 / 95 \mathrm{v} / \mathrm{v}$ ethyl acetate/hexane gradient elution) and two fractions, $\mathrm{C}$ and $\mathrm{D}$, were thereby obtained.

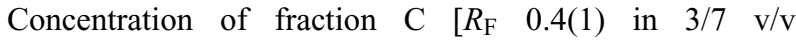
ethyl acetate/hexane] afforded the syn-isomer of compound 9, i.e., $(3 \mathrm{a} R, 4 S, 4 \mathrm{a} S, 7 \mathrm{a} S, 8 R, 8 \mathrm{a} S)-3 \mathrm{a}, 4,4 \mathrm{a}, 6,7,7 \mathrm{a}, 8,8 \mathrm{a}-$ octahydro2,2,4-trimethyl-4,8-etheno-5H-indeno[5,6- $d]$-1,3-dioxol-5-one $(169 \mathrm{mg}, 7 \%)$ as a clear, colourless oil. The spectroscopic data derived from this material were identical, in all respects, with those reported earlier. ${ }^{[8]}$

Concentration of fraction $\mathrm{D}\left[R_{\mathrm{F}} 0.3(9)\right.$ in $3 / 7 \mathrm{v} / \mathrm{v}$ ethyl acetate/hexane] afforded the Diels-Alder dimer of the starting material, i.e., [3a $R-(3 \mathrm{a} \alpha, 5 \mathrm{a} \beta, 6 \alpha, 6 \mathrm{a} \beta, 9 \mathrm{a} \beta, 10 \alpha, 10 \mathrm{a} \beta, 10 \mathrm{~b} \beta)]-$ 3a,5a,6,6a,9a, 10,10a,10b-octahydro-2,2,4,6,8,8-hexamethyl-6, 10-ethenonaphtho-[1,2-d:6,7- $\left.d^{\prime}\right]$ bis[1,3]dioxole $(589 \mathrm{mg}, 19 \%)$ as a clear, colourless oil. The spectroscopic data derived from this material were identical, in all respects, with those reported earlier. ${ }^{[8]}$
Methyl (3aR, 4R, 4aR,6R,7aR,8S,8aS)-

3a, 4a, 5, 6, 7, 7a, 8, 8a-Octahydro-2,2, 4, 6-tetramethyl-

5-oxo-4,8-etheno-4H-indeno[5,6-d]-

\section{1,3-dioxole-6-carboxylate (10)}

Step (i): Following earlier procedures, the enolate obtained by deprotonation of ketone 9 (108 $\mathrm{mg}, 0.434 \mathrm{mmol})$ with $\mathrm{LiH}-$ MDS was treated with Mander's reagent ${ }^{[14]}$ to give, after workup and flash chromatographic purification, a mixture of methyl $(3 \mathrm{a} R, 4 R, 4 \mathrm{a} R, 6 R, 7 \mathrm{a} R, 8 S, 8 \mathrm{a} S)-3 \mathrm{a}, 4 \mathrm{a}, 5,6,7,7 \mathrm{a}, 8,8 \mathrm{a}-$ octahydro- 2,2 , 4-trimethyl-5-oxo-4,8-etheno-4H-indeno[5,6- $d$ ]-1,3-dioxole-6carboxylate and various tautomers $(111 \mathrm{mg}, 84 \%)$ as a white crystalline solid, mp $130-138^{\circ} \mathrm{C},[\alpha]_{\mathrm{D}}+112\left(\sim 0.8, \mathrm{CHCl}_{3}\right)$ $\left(R_{\mathrm{F}} 0.3\right.$ in $3 / 7 \mathrm{v} / \mathrm{v}$ ethyl acetate/hexane) (Found: $\mathrm{M}^{+} \cdot 306.1470$. $\mathrm{C}_{17} \mathrm{H}_{22} \mathrm{O}_{5}$ requires $\left.\mathrm{M}^{+} \cdot 306.1467\right) . v_{\max }(\mathrm{NaCl}) / \mathrm{cm}^{-1} 3435$, 2925, 1751, 1733, 1658, 1623, 1456, 1379, 1262, 1211, 1037, 884, 795. $\mathrm{m} / \mathrm{z}(\mathrm{EI}, 70 \mathrm{eV}) 306\left(\mathrm{M}^{+\bullet}, 22 \%\right), 291(30), 248(69)$, 233 (20), 216 (25), 134 (46), 108 (100), 100 (81), 91 (33), 85 (35), 55 (53), 43 (57).

Step (ii): A magnetically stirred solution of methyl (3a $R, 4 R, 4 \mathrm{a} R, 6 R, 7 \mathrm{a} R, 8 S, 8 \mathrm{a} S)-3 \mathrm{a}, 4 \mathrm{a}, 5,6,7,7 \mathrm{a}, 8,8 \mathrm{a}-0$ ctahydro-2,2, 4-trimethyl-5-oxo-4,8-etheno- $4 H$-indeno-[5,6- $d]$-1,3-dioxole-6carboxylate and its various tautomers $(392 \mathrm{mg}, 1.28 \mathrm{mmol})$ in acetone $(13 \mathrm{~mL})$ was treated with $\mathrm{K}_{2} \mathrm{CO}_{3}(195 \mathrm{mg}, 1.41 \mathrm{mmol})$ then MeI $(96 \mu \mathrm{L}, 1.54 \mathrm{mmol})$ and the ensuing mixture stirred at $18^{\circ} \mathrm{C}$ for $24 \mathrm{~h}$ then filtered through Celite and the filtrate concentrated under reduced pressure. The resulting light-yellow oil was subjected to flash chromatography (silica, 3:7 v/v ethyl acetate/hexane elution). Concentration of the appropriate fractions ( $R_{\mathrm{f}} 0.2$ in 3:7 v/v ethyl acetate/hexane) under reduced pressure affording the keto-ester $\mathbf{1 0}^{[8]}(401 \mathrm{mg}, 98 \%)$ as white needles, mp $93-96^{\circ} \mathrm{C}$ (lit. ${ }^{[8]} 92-96^{\circ} \mathrm{C}$ ). The spectroscopic data derived from this material were identical, in all respects, with those reported earlier. ${ }^{[8]}$

\section{Methyl (3aR, 4R, 4aR, 6S, 7aR, 8S, 8aS)-}

3a, 4a, 5, 6,7,7a,8,8a-Octahydro-5-hydroxy-

2,2,4,6-tetramethyl-4,8-etheno-4H-indeno[5, 6-d]-

1,3-dioxole-6-carboxylate (11)

Method A: A magnetically stirred solution of ketone $\mathbf{1 0}$ $(120 \mathrm{mg}, 0.37 \mathrm{mmol})$ and $\mathrm{CeCl}_{3} \cdot 7 \mathrm{H}_{2} \mathrm{O}(278 \mathrm{mg}, 0.75 \mathrm{mmol})$ in methanol $(10 \mathrm{~mL})$ was cooled to $0^{\circ} \mathrm{C}$ then treated, in portions over a $0.5 \mathrm{~h}$ period, with $\mathrm{NaBH}_{4}(28 \mathrm{mg}, 0.75 \mathrm{mmol})$. The mixture was allowed to warm up to $18^{\circ} \mathrm{C}$ and stirred at this temperature for $3.25 \mathrm{~h}$. Water $(20 \mathrm{~mL})$ was then added slowly and after gas evolution had ceased the reaction mixture was concentrated under reduced pressure. The residue thus obtained was extracted with dichloromethane $(4 \times 20 \mathrm{~mL})$ and the combined organic phases were dried $\left(\mathrm{Na}_{2} \mathrm{SO}_{4}\right)$ and filtered before being concentrated under reduced pressure to give a white solid. Recrystallization (hexane-methanol) of this material afforded the title hydroxy-ester $\mathbf{1 1}(88.2 \mathrm{mg}, 73 \%)$ as a white crystalline solid, mp $90-91^{\circ} \mathrm{C},[\alpha]_{\mathrm{D}}+7\left(c 1.0, \mathrm{CHCl}_{3}\right), R_{\mathrm{F}} 0.2(3: 7 \mathrm{v} / \mathrm{v}$ ethyl acetate/hexane) (Found: $\mathrm{M}^{+\bullet} 322.1782 ; \mathrm{C}$ 67.0, H 7.9. $\mathrm{C}_{18} \mathrm{H}_{26} \mathrm{O}_{5}$ requires $\left.\mathrm{M}^{+} \cdot 322.1780 ; \mathrm{C} 67.1, \mathrm{H} 8.1 \%\right) . \delta_{\mathrm{H}}\left(\mathrm{CDCl}_{3}\right.$, $300 \mathrm{MHz}) 6.00(\mathrm{t}, J 6.6,1 \mathrm{H}), 5.79(\mathrm{~d}, J 8.1,1 \mathrm{H}), 4.17(\mathrm{~m}, 1 \mathrm{H})$, $3.88(\mathrm{~d}, J 8.1,1 \mathrm{H}), 3.78(\mathrm{~d}, J 8.1,1 \mathrm{H}), 3.62(\mathrm{~s}, 3 \mathrm{H}), 2.66(\mathrm{~m}$, 1H), 2.47 (br s, 1H), $2.19(\mathrm{~m}, 1 \mathrm{H}), 1.70(\mathrm{~m}, 1 \mathrm{H}), 1.54(\mathrm{~m}, 1 \mathrm{H})$, $1.40(\mathrm{~m}, 1 \mathrm{H}), 1.29(\mathrm{~s}, 3 \mathrm{H}), 1.26(\mathrm{~s}, 3 \mathrm{H}), 1.22(\mathrm{~s}, 3 \mathrm{H}), 1.15(\mathrm{~s}$, $3 \mathrm{H}) . \delta_{\mathrm{C}}\left(\mathrm{CDCl}_{3}, 75 \mathrm{MHz}\right) 177.0(\mathrm{C}), 135.7(\mathrm{CH}), 130.3(\mathrm{CH})$,

${ }^{*}$ Compound 7 can be obtained from Questor, Queen's University of Belfast, Northern Ireland (see: http://questor.qub.ac.uk/newsite/contact.htm). 
$108.4(\mathrm{C}), 82.7(\mathrm{CH}), 79.0,(\mathrm{CH}), 77.7(\mathrm{CH}), 51.6\left(\mathrm{CH}_{3}\right), 51.4$ (C), $48.7(\mathrm{CH}), 40.5(\mathrm{C}), 38.3(\mathrm{CH}), 37.0(\mathrm{CH}), 36.9\left(\mathrm{CH}_{2}\right), 25.1$ $\left(\mathrm{CH}_{3}\right), 24.5\left(\mathrm{CH}_{3}\right), 18.8\left(\mathrm{CH}_{3}\right), 16.8\left(\mathrm{CH}_{3}\right) \cdot v_{\max }(\mathrm{NaCl}) / \mathrm{cm}^{-1}$ 3500, 2955, 2930, 2870, 1731, 1634, 1460, 1378, 1289, 1260, $1210,1167,1119,1072,886 . \mathrm{m} / \mathrm{z}(\mathrm{EI}, 70 \mathrm{eV}) 322\left(\mathrm{M}^{+\bullet}, 12 \%\right)$, 307 (55), 264 (98), 222 (100), 187 (49), 186 (53), 157 (42), 144 (65), 119 (64), 105 (65), 91 (55), 85 (42), 43 (70).

Method B: A magnetically stirred solution of ketone $\mathbf{1 0}$ $(80 \mathrm{mg}, 0.25 \mathrm{mmol})$ in methanol $(1.3 \mathrm{~mL})$ was cooled to $0^{\circ} \mathrm{C}$ and then treated, in portions over $0.5 \mathrm{~h}$, with $\mathrm{NaBH}_{4}(19 \mathrm{mg}$, $0.50 \mathrm{mmol})$. The ensuing mixture was warmed to $18^{\circ} \mathrm{C}$ and stirred at this temperature for $3.25 \mathrm{~h}$ before being re-cooled to $0^{\circ} \mathrm{C}$ and treated with another portion of $\mathrm{NaBH}_{4}(19 \mathrm{mg}$, $0.50 \mathrm{mmol})$. The reaction mixture so obtained was re-warmed to $18^{\circ} \mathrm{C}$, stirred at this temperature for $2 \mathrm{~h}$, and then quenched by the slow addition of water $(15 \mathrm{~mL})$. After gas evolution had ceased $(\sim 0.2 \mathrm{~h})$ the reaction mixture was concentrated under reduced pressure and the residue extracted with dichloromethane $(4 \times 10 \mathrm{~mL})$. The combined organic phases were then dried $\left(\mathrm{Na}_{2} \mathrm{SO}_{4}\right)$, filtered, and concentrated under reduced pressure to give an off-white solid. Subjection of this material to flash chromatography (silica, 1/20 v/v ethyl acetate/hexane elution) afforded two fractions, $\mathrm{A}$ and $\mathrm{B}$.

Concentration of fraction A $\left(R_{\mathrm{F}} \quad 0.2\right.$ in $3 / 7 \mathrm{v} / \mathrm{v}$ ethyl acetate/hexane) afforded hydroxyl ester 11 (19 mg, 23\%) as a white, crystalline solid. This material was identical, in all respects, with an authentic sample prepared by Method A as detailed immediately above.

Concentration of fraction $\mathrm{B}$ afforded the $\mathrm{C} 5$-epimer of compound 11, i.e., $(3 a \mathrm{R}, 4 \mathrm{R}, 4 a \mathrm{R}, 5 \mathrm{~S}, 6 \mathrm{R}, 7 a \mathrm{R}, 8 \mathrm{~S}, 8 a \mathrm{~S})-$ $3 a, 4 a, 5,6,7,7 a, 8,8 a$-octahydro-5-hydroxy-2,2,4,6-tetramethyl-4, 8-etheno-4H-indeno[5,6-d]-1,3-dioxole-6-carboxylate (36 mg, $45 \%)$ as a white crystalline solid, mp $129-131^{\circ} \mathrm{C},[\alpha]_{\mathrm{D}}-7(c$ $\left.0.9, \mathrm{CHCl}_{3}\right), R_{\mathrm{F}} 0.25\left(3 / 7 \mathrm{v} / \mathrm{v}\right.$ ethyl acetate/hexane) (Found: $\mathrm{M}^{+} \cdot$ 322.1782; C 67.3, H 8.5. $\mathrm{C}_{18} \mathrm{H}_{26} \mathrm{O}_{5}$ requires $\mathrm{M}^{+}$? 322.1780; C 67.1, H 8.1\%). $\delta_{\mathrm{H}}\left(\mathrm{CDCl}_{3}, 300 \mathrm{MHz}\right) 6.06(\mathrm{~m}, 2 \mathrm{H}), 4.25(\mathrm{~m}$, $1 \mathrm{H}), 4.00(\mathrm{dd}, J 5.9$ and $3.6,1 \mathrm{H}), 3.84(\mathrm{dd}, J 6.9$ and $0.6,1 \mathrm{H})$, $3.67(\mathrm{~s}, 3 \mathrm{H}), 2.87(\mathrm{~m}, 1 \mathrm{H}), 2.23(\mathrm{~m}, 1 \mathrm{H}), 2.05-1.96$ (complex $\mathrm{m}, 2 \mathrm{H}), 1.83(\mathrm{~m}, 1 \mathrm{H}), 1.69(\mathrm{~m}, 1 \mathrm{H}), 1.38(\mathrm{~s}, 3 \mathrm{H}), 1.31(\mathrm{~s}, 3 \mathrm{H})$, $1.27(\mathrm{~s}, 3 \mathrm{H}), 1.16(\mathrm{~s}, 3 \mathrm{H}) . \delta_{\mathrm{C}}\left(\mathrm{CDCl}_{3}, 75 \mathrm{MHz}\right) 175.4(\mathrm{C}), 137.6$ $(\mathrm{CH}), 130.1(\mathrm{CH}), 109.1(\mathrm{C}), 83.4(\mathrm{CH}), 80.2(\mathrm{CH}), 80.0(\mathrm{CH})$, $56.7\left(\mathrm{CH}_{3}\right), 51.8(\mathrm{C}), 49.4(\mathrm{CH}), 40.4(\mathrm{CH}), 39.8(\mathrm{CH}), 38.0(\mathrm{C})$, $35.4\left(\mathrm{CH}_{2}\right), 25.4\left(\mathrm{CH}_{3}\right), 24.9\left(\mathrm{CH}_{3}\right), 20.6\left(\mathrm{CH}_{3}\right), 19.5\left(\mathrm{CH}_{3}\right)$ $v_{\max }(\mathrm{NaCl}) / \mathrm{cm}^{-1} 3498,2963,2921,2871,1716,1635,1463$, 1439, 1377, 1328, 1298, 1270, 1243, 1215, 1167, 1136, 1086, 1071, 1055, 1038, 992, 895, 879, 831, 724. $\mathrm{m} / \mathrm{z}(\mathrm{EI}, 70 \mathrm{eV}) 322$ $\left(\mathrm{M}^{+\bullet}, 8 \%\right), 307$ (46), 264 (32), 233 (48), 222 (235), 186 (49), 186 (53), 157 (50), 144 (86), 119 (74), 106 (100), 91 (51), 69 (61), 43 (75).

\section{Methyl (3aR,4R,4aR,5R,6R,7aR,8S,8aS)-}

3a, 4a, 5, 6,7,7a,8,8a-Octahydro-2,2,4,6-

tetramethyl-5-(octanoyloxy)-4,8-etheno-4H-

indeno[5,6-d]-1,3-dioxole-6-carboxylate (12)

A magnetically stirred solution of alcohol $11(1.11 \mathrm{~g}$, $3.44 \mathrm{mmol})$ in dichloromethane $(30 \mathrm{~mL})$ was cooled to $-78^{\circ} \mathrm{C}$ and then treated with DMAP $(1.05 \mathrm{~g}, 8.59 \mathrm{mmol})$. The resulting solution was allowed to stir at $-78^{\circ} \mathrm{C}$ for $0.25 \mathrm{~h}$ and then treated with octanoyl chloride $(650 \mu \mathrm{L}, 3.80 \mathrm{mmol})$. Stirring was continued at $-78^{\circ} \mathrm{C}$ for $0.25 \mathrm{~h}$ and then the reaction mixture was warmed to $18^{\circ} \mathrm{C}$ and stirring continued at this temperature for $1.5 \mathrm{~h}$. Further portions of DMAP $(526 \mathrm{mg}, 4.30 \mathrm{mmol})$ and octanoyl chloride $(325 \mu \mathrm{L}, 1.90 \mathrm{mmol})$ were added to the reaction mixture which was then left to stir at $18^{\circ} \mathrm{C}$ for $18 \mathrm{~h}$. After this time $\mathrm{HCl}(40 \mathrm{~mL}$ of a $1.0 \mathrm{M}$ aqueous solution) was added to the reaction mixture and the separated aqueous phase was extracted with dichloromethane $(3 \times 30 \mathrm{~mL})$. The combined organic phases were dried $\left(\mathrm{Na}_{2} \mathrm{SO}_{4}\right)$, filtered, and concentrated under reduced pressure and the yellow oil thus obtained was subjected to flash chromatography (silica, $1 / 20 \mathrm{v} / \mathrm{v}$ ethyl acetate/hexane elution). Concentration of the appropriate fractions ( $R_{\mathrm{F}} 0.4$ in $3 / 7 \mathrm{v} / \mathrm{v}$ ethyl acetate/hexane) under reduced pressure then afforded the title octanoyl ester $12(1.25 \mathrm{~g}, 81 \%)$ as a clear, colourless oil, $[\alpha]_{\mathrm{D}}+20\left(c 1.3, \mathrm{CHCl}_{3}\right)$ [Found: $\left(\mathrm{M}-\mathrm{CH}_{3} \bullet\right)^{+}$433.2591; C 69.6, $\mathrm{H} \mathrm{8.8.} \mathrm{C}_{26} \mathrm{H}_{40} \mathrm{O}_{6}$ requires $\left.\left(\mathrm{M}-\mathrm{CH}_{3} \bullet\right)^{+} 433.2590 ; \mathrm{C} 69.6, \mathrm{H} 9.0 \%\right] . \delta_{\mathrm{H}}\left(\mathrm{CDCl}_{3}, 300 \mathrm{MHz}\right)$ $6.00(\mathrm{~m}, 1 \mathrm{H}), 5.75(\mathrm{~d}, J 8.2,1 \mathrm{H}), 4.92(\mathrm{~d}, J 8.4,1 \mathrm{H}) 4.12(\mathrm{dd}, J$ 7.2 and $6.9,1 \mathrm{H}), 3.70(\mathrm{~d}, J 7.2,1 \mathrm{H}), 3.50(\mathrm{~s}, 3 \mathrm{H}), 2.63(\mathrm{~m}, 1 \mathrm{H})$, $2.15(\mathrm{~m}, 2 \mathrm{H}), 1.75(\mathrm{~m}, 2 \mathrm{H}), 1.64-1.42$ (complex m, 3H), 1.241.10 (complex m, 12H), $1.19(\mathrm{~s}, 3 \mathrm{H}), 1.02(3)(\mathrm{s}, 3 \mathrm{H}), 1.01(9)(\mathrm{s}$, $3 \mathrm{H}), 0.75(\mathrm{~m}, 3 \mathrm{H}) . \delta_{\mathrm{C}}\left(\mathrm{CDCl}_{3}, 75 \mathrm{MHz}\right) 175.3(\mathrm{C}), 172.3(\mathrm{C})$, $135.2(\mathrm{CH}), 130.9(\mathrm{CH}), 108.8(\mathrm{C}), 82.5(\mathrm{CH}), 79.3(\mathrm{CH}), 79.1$ $(\mathrm{CH}), 51.7\left(\mathrm{CH}_{3}\right), 51.0(\mathrm{C}), 48.1(\mathrm{CH}), 40.5(\mathrm{C}), 38.4(3)\left(\mathrm{CH}_{2}\right)$, 38.4(0) $(\mathrm{CH}), 37.4(\mathrm{CH}), 34.0\left(\mathrm{CH}_{2}\right), 31.4\left(\mathrm{CH}_{2}\right), 28.7\left(\mathrm{CH}_{2}\right)$, $28.6\left(\mathrm{CH}_{2}\right), 25.2\left(\mathrm{CH}_{3}\right), 24.7\left(\mathrm{CH}_{2}\right), 24.6\left(\mathrm{CH}_{3}\right), 22.3\left(\mathrm{CH}_{2}\right)$, $18.5\left(\mathrm{CH}_{3}\right), 16.9\left(\mathrm{CH}_{3}\right), 13.8\left(\mathrm{CH}_{3}\right) \cdot v_{\max }(\mathrm{NaCl}) / \mathrm{cm}^{-1} 2932$, $1737,1462,1378,1263,1212,1166,1115,1091,885,734 . \mathrm{m} / \mathrm{z}$ $(\mathrm{EI}, 70 \mathrm{eV}) 433\left[\left(\mathrm{M}-\mathrm{CH}_{3}^{*}\right)^{+}, 25 \%\right], 246(100), 204(40), 187$ (82), 186 (95), 144 (89), 57 (48).

\section{Methyl (2R,3R,3aR,4S,7S,7aR,8S,9R)-}

2,3,3a,4,7,7a-Hexahydro-8,9-dihydroxy-2,4dimethyl-3-(octanoyloxy)-4,7-ethano-

$1 \mathrm{H}$-indene-2-carboxylate (13)

A magnetically stirred solution of acetonide 12 (486 mg, $1.08 \mathrm{mmol})$ in methanol/water $(12 \mathrm{~mL}$ of a $5 / 1 \mathrm{v} / \mathrm{v}$ mixture $)$ was treated with DOWEX-50 resin [540 mg that had been washed successively with $\mathrm{NaHCO}_{3}$ (saturated aqueous solution), water, $\mathrm{HCl}$ (1 $\mathrm{M}$ aqueous solution), and water]. The ensuing mixture was heated at $110^{\circ} \mathrm{C}$ until TLC analysis indicated that all of the starting material had been consumed (approx. 3-4 days). The cooled mixture was filtered and the solid thus retained was washed with methanol $(3 \times 50 \mathrm{~mL})$ and dichloromethane $(3 \times 25 \mathrm{~mL})$. The combined filtrates were concentrated under reduced pressure, the residue was diluted with $\mathrm{NaCl}(30 \mathrm{~mL}$ of a $1.5 \mathrm{M}$ aqueous solution) and the resulting mixture extracted with dichloromethane $(5 \times 20 \mathrm{~mL})$. The combined organic phases were then dried $\left(\mathrm{Na}_{2} \mathrm{SO}_{4}\right)$, filtered, and concentrated under reduced pressure to afford the title diol $13(344 \mathrm{mg}, 78 \%)$ as a clear, colourless oil, $[\alpha]_{\mathrm{D}}+21\left(c 1.2, \mathrm{CHCl}_{3}\right), R_{\mathrm{F}} 0.2(1 / 1$ $\mathrm{v} / \mathrm{v}$ ethyl acetate/hexane) (Found: $\mathrm{M}^{+} \cdot 408.2510 . \mathrm{C}_{23} \mathrm{H}_{36} \mathrm{O}_{6}$ requires $\left.\mathrm{M}^{+} \cdot 408.2512\right)$. $\delta_{\mathrm{H}}\left(\mathrm{CDCl}_{3}, 300 \mathrm{MHz}\right) 6.28(\mathrm{~m}, 1 \mathrm{H})$, $6.01(\mathrm{~d}, J 6.9,1 \mathrm{H}), 5.00(\mathrm{~d}, J 8.1,1 \mathrm{H}), 3.92(\mathrm{~m}, 1 \mathrm{H}), 3.62(\mathrm{~s}$, $3 \mathrm{H}), 3.45(\mathrm{~m}, 1 \mathrm{H}), 2.73(\mathrm{~m}, 1 \mathrm{H}), 2.46-2.23$ (complex m, 5H), 1.94-1.53 (complex m, 5H), 1.34-1.20 (complex m, 8H), 1.16 (s, 3H), $1.13(\mathrm{~s}, 3 \mathrm{H}), 0.87(\mathrm{~m}, 3 \mathrm{H}) . \delta_{\mathrm{C}}\left(\mathrm{CDCl}_{3}, 75 \mathrm{MHz}\right) 175.7$ (C), $172.7(\mathrm{C}), 136.1(\mathrm{CH}), 132.0(\mathrm{CH}), 79.8(\mathrm{CH}), 73.7(\mathrm{CH})$, $70.6(\mathrm{CH}), 51.9\left(\mathrm{CH}_{3}\right), 50.4(\mathrm{C}), 48.8(\mathrm{CH}), 41.8(\mathrm{C}), 41.2(\mathrm{CH})$, $38.5\left(\mathrm{CH}_{2}\right), 37.9(\mathrm{CH}), 34.2\left(\mathrm{CH}_{2}\right), 31.4\left(\mathrm{CH}_{2}\right), 28.8\left(\mathrm{CH}_{2}\right), 28.7$ $\left(\mathrm{CH}_{2}\right), 24.7\left(\mathrm{CH}_{2}\right), 22.3\left(\mathrm{CH}_{2}\right), 18.3\left(\mathrm{CH}_{3}\right), 16.9\left(\mathrm{CH}_{3}\right), 13.9$ $\left(\mathrm{CH}_{3}\right) \cdot v_{\max }(\mathrm{NaCl}) / \mathrm{cm}^{-1} 3443,2929,2857,1736,1463,1434$, 1376, 1251, 1206, 1169, 1112, 1093, 1057, 1001, 908, 784, 731. $\mathrm{m} / \mathrm{z}$ (EI, $70 \mathrm{eV}) 408\left(\mathrm{M}^{+\bullet},<1 \%\right), 204$ (26), 144 (100), 105 (12), 57 (21), 43 (12). 
Methyl (2R,3R,3aR,4S, 7S, 7aS, 9R)-2,3,3a,4,7,7aHexahydro-9-hydroxy-2,4-dimethyl-3-(octanoyloxy)8-oxo-4,7-ethano-1H-indene-2-carboxylate (14)

A magnetically stirred solution of diol 13 (369 mg, $0.90 \mathrm{mmol})$ in dichloromethane $(12 \mathrm{~mL})$ was cooled to $0^{\circ} \mathrm{C}$ and treated with $p$ - $\mathrm{TsOH} \cdot \mathrm{H}_{2} \mathrm{O}(378 \mathrm{mg}, 1.99 \mathrm{mmol})$. 4-AcetamidoTEMPO (424 mg, $1.99 \mathrm{mmol})$ was then added in portions over $2 \mathrm{~h}$, and the ensuing mixture was stirred at $0^{\circ} \mathrm{C}$ for $2 \mathrm{~h}$. After this time the reaction mixture was warmed to $18^{\circ} \mathrm{C}$ and stirred at this temperature for a further $3 \mathrm{~h} . \mathrm{NaHCO}_{3}(10 \mathrm{~mL}$ of a saturated aqueous solution) was then added and the separated aqueous phase was extracted with dichloromethane $(5 \times 10 \mathrm{~mL})$. The combined organic phases were then dried $\left(\mathrm{Na}_{2} \mathrm{SO}_{4}\right)$, filtered, and concentrated under reduced pressure to yield a light-yellow oil. Subjection of this material to flash chromatography (silica, $1 / 5 \rightarrow 1 / 1 \mathrm{v} / \mathrm{v}$ ethyl acetate/hexane gradient elution) afforded two fractions, A and B.

Concentration of fraction A $\left(R_{\mathrm{F}} 0.2\right.$ in $1 / 1 \mathrm{v} / \mathrm{v}$ ethyl acetate/hexane) afforded the starting diol $13(28 \mathrm{mg}, 8 \%$ recovery) as a clear, colourless oil. This material was identical, in all respects, with an authentic sample.

Concentration of fraction B $\left(R_{\mathrm{F}} \quad 0.5\right.$ in $1 / 1$ v/v ethyl acetate/hexane) gave the title acyloin $14(319 \mathrm{mg}, 94 \%$ at $92 \%$ conversion) as a clear, colourless oil, $[\alpha]_{\mathrm{D}}+93\left(c 1.0, \mathrm{CHCl}_{3}\right)$ (Found: $\mathrm{M}^{+\bullet}$ 406.2359. $\mathrm{C}_{23} \mathrm{H}_{34} \mathrm{O}_{6}$ requires $\mathrm{M}^{+\bullet}$ 406.2355). $\delta_{\mathrm{H}}$ $\left(\mathrm{CDCl}_{3}, 300 \mathrm{MHz}\right) 6.20(\mathrm{~m}, 2 \mathrm{H}), 5.13(\mathrm{~d}, J 8.7,1 \mathrm{H}), 3.63(\mathrm{~s}$, $3 \mathrm{H}), 3.37(\mathrm{~s}, 1 \mathrm{H}), 3.14(\mathrm{~m}, 1 \mathrm{H}), 2.72(\mathrm{~m}, 2 \mathrm{H}), 2.28(\mathrm{~m}, 3 \mathrm{H})$, 1.97-1.79 (complex m, 2H), 1.60 (m, 2H), 1.30-1.23 (complex $\mathrm{m}, 8 \mathrm{H}), 1.22(\mathrm{~s}, 3 \mathrm{H}), 1.18(\mathrm{~s}, 3 \mathrm{H}), 0.87(\mathrm{~m}, 3 \mathrm{H}) . \delta_{\mathrm{C}}\left(\mathrm{CDCl}_{3}\right.$, $75 \mathrm{MHz}) 210.5(\mathrm{C}), 175.2(\mathrm{C}), 172.7(\mathrm{C}), 140.2(\mathrm{CH}), 127.3$ $(\mathrm{CH}), 79.2(\mathrm{CH}), 74.0(\mathrm{CH}), 52.2\left(\mathrm{CH}_{3}\right), 50.6(2)(\mathrm{C}), 50.5(8)$ $(\mathrm{CH}), 50.4(\mathrm{CH}), 44.2(\mathrm{C}), 38.1\left(\mathrm{CH}_{2}\right), 36.1(\mathrm{CH}), 34.3\left(\mathrm{CH}_{2}\right)$, $31.6\left(\mathrm{CH}_{2}\right), 29.0\left(\mathrm{CH}_{2}\right), 28.9\left(\mathrm{CH}_{2}\right), 25.0\left(\mathrm{CH}_{2}\right), 22.6\left(\mathrm{CH}_{2}\right)$, 17.2(1) $\left(\mathrm{CH}_{3}\right), 17.1(8)\left(\mathrm{CH}_{3}\right), 14.1\left(\mathrm{CH}_{3}\right) \cdot v_{\max }(\mathrm{NaCl}) / \mathrm{cm}^{-1}$ 3456, 2928, 2856, 1734, 1463, 1377, 1264, 1208, 1169, 1114, 1079, 772, 698. $\mathrm{m} / \mathrm{z}(\mathrm{EI}, 70 \mathrm{eV}) 406\left(\mathrm{M}^{+\bullet},<1 \%\right), 262(14), 202$ (100), 174 (29), 145 (73), 127 (23), 57 (51), 43 (35).

\section{Methyl (2R,3R,3aR, 4S, 7S,7aS, 9R)-9-(Benzoyloxy)-}

2,3,3a,4,7,7a-hexahydro-2,4-dimethyl-3-(octanoyloxy)8-oxo-4,7-ethano-1H-indene-2-carboxylate (15)

A magnetically stirred solution of acyloin $14(621 \mathrm{mg}$, $1.53 \mathrm{mmol})$ in dichloromethane $(16 \mathrm{~mL})$ was cooled to $0^{\circ} \mathrm{C}$ and treated with DMAP $(775 \mathrm{mg}, 6.34 \mathrm{mmol})$. Benzoyl chloride $(550 \mu \mathrm{L}, 4.73 \mathrm{mmol})$ was then added and the reaction mixture left to stir at $0^{\circ} \mathrm{C}$ for $0.25 \mathrm{~h}$ and then allowed to warm to $18^{\circ} \mathrm{C}$ and stirred at this temperature for $18 \mathrm{~h}$. After this time the reaction mixture was quenched with $\mathrm{HCl}(20 \mathrm{~mL}$ of a $1.0 \mathrm{M}$ aqueous solution) and the ensuing mixture was extracted with dichloromethane $(3 \times 15 \mathrm{~mL})$. The combined organic phases were then dried $\left(\mathrm{Na}_{2} \mathrm{SO}_{4}\right)$, filtered, and concentrated under reduced pressure to give a white solid. Subjection of this material to flash chromatography (silica, $1 / 4 \rightarrow 3 / 7 \mathrm{v} / \mathrm{v}$ ethyl acetate/hexane gradient elution) and concentration of the appropriate fractions $\left(R_{\mathrm{F}} 0.4\right.$ in $3 / 7 \mathrm{v} / \mathrm{v}$ ethyl acetate/hexane) under reduced pressure afforded the title benzoate $32(633 \mathrm{mg}$, $81 \%)$ as a white crystalline solid, mp $93-94^{\circ} \mathrm{C},[\alpha]_{\mathrm{D}}+158(c$ $0.75, \mathrm{CHCl}_{3}$ ) (Found: $\mathrm{M}^{+} \bullet$ 510.2625. $\mathrm{C}_{30} \mathrm{H}_{38} \mathrm{O}_{7}$ requires $\mathrm{M}^{+} \bullet$ 510.2618). $\delta_{\mathrm{H}}\left(\mathrm{CDCl}_{3}, 300 \mathrm{MHz}\right) 8.00(\mathrm{~m}, 2 \mathrm{H}), 7.57(\mathrm{~m}, 1 \mathrm{H})$, $7.43(\mathrm{~m}, 2 \mathrm{H}), 6.36(\mathrm{~m}, 1 \mathrm{H}), 6.27(\mathrm{~d}, J 7.9,1 \mathrm{H}), 5.16(\mathrm{~d}, J 8.4$, $1 \mathrm{H}), 5.12(\mathrm{~s}, 1 \mathrm{H}), 3.65(\mathrm{~s}, 3 \mathrm{H}), 3.23(\mathrm{dm}, J 6.3,1 \mathrm{H}), 2.86(\mathrm{~m}$, 1H), 2.49 (m, 1H), 2.29 (m, 2H), 2.02-1.84 (complex m, 2H), $1.60(\mathrm{~m}, 2 \mathrm{H}), 1.34-1.21$ (complex m, 8H), 1.22 (s, 3H), 1.12 (s, 3H), $0.87(\mathrm{~m}, 3 \mathrm{H}) . \delta_{\mathrm{C}}\left(\mathrm{CDCl}_{3}, 75 \mathrm{MHz}\right) 204.0(\mathrm{C}), 174.7$ (C), $172.2(\mathrm{C}), 165.6(\mathrm{C}), 138.9(\mathrm{CH}), 133.0(\mathrm{CH}), 129.5(\mathrm{CH})$, $128.9(\mathrm{CH}), 128.1(\mathrm{CH}), 127.7(\mathrm{C}), 78.9(\mathrm{CH}), 73.0(\mathrm{CH}), 51.8$ $\left(\mathrm{CH}_{3}\right), 50.9(\mathrm{C}), 50.3(\mathrm{CH}), 49.6(\mathrm{CH}), 42.9(\mathrm{C}), 37.7\left(\mathrm{CH}_{2}\right)$, $36.1(\mathrm{CH}), 33.9\left(\mathrm{CH}_{2}\right), 31.3\left(\mathrm{CH}_{2}\right), 28.7\left(\mathrm{CH}_{2}\right), 28.5\left(\mathrm{CH}_{2}\right)$, $24.6\left(\mathrm{CH}_{2}\right), 22.2\left(\mathrm{CH}_{2}\right), 16.9\left(\mathrm{CH}_{3}\right), 16.7\left(\mathrm{CH}_{3}\right), 13.7\left(\mathrm{CH}_{3}\right)$. $v_{\max }(\mathrm{NaCl}) / \mathrm{cm}^{-1} 2929,2857,1739,1602,1584,1463,1451$, 1377, 1317, 1265, 1175, 1114, 1071, 1027, 1000, 763, 711. $\mathrm{m} / \mathrm{z}$ (EI, $70 \mathrm{eV}) 510\left(\mathrm{M}^{+\bullet}, 1 \%\right), 479$ (2), 244 (48), $216(17), 204$ (9), 144 (28), 105 (100), 77 (11), 57 (14), 43 (8).

\section{Methyl (1R,2aR,2bR,2cR,4R,5R,5aR,5bR,5cS)- 1-(Benzoyloxy)-decahydro-4,5b-dimethyl- \\ 5-(octanoyloxy)-2-oxo- $1 \mathrm{H}$ - \\ cyclopenta[a]cyclopropa[cd]pentalene- \\ 4-carboxylate (16) and \\ Methyl (1S,2aR,2bR,2cR,4R,5R,5aR,5bR,5cS)- \\ 1-(Benzoyloxy)-decahydro-4,5b-dimethyl-5- (octanoyloxy)-2-oxo-1H-cyclopenta[a]- \\ cyclopropa[cd]pentalene-4-carboxylate (17)}

Method A: A deoxygenated solution of compound $\mathbf{1 5}$ (335 mg, $0.65 \mathrm{mmol})$ and acetophenone $(192 \mu \mathrm{L}, 1.64 \mathrm{mmol})$ in acetone $(120 \mathrm{~mL})$ all contained in a Pyrex vessel jacketed by a water-cooled $\left(5-10^{\circ} \mathrm{C}\right)$ solution of sodium bromide $(750 \mathrm{~g})$ and lead(II) nitrate $(8 \mathrm{~g})$ in water $(1000 \mathrm{~mL})$ was subjected to irradiation with a Philips $125 \mathrm{~W}$ HPL-N lamp for $120 \mathrm{~h}$. The reaction mixture was then concentrated under reduced pressure and the ensuing pale-yellow oil subjected to flash chromatography (silica, 5:95 $\rightarrow 3: 7 \mathrm{v} / \mathrm{v}$ ethyl acetate/hexane gradient elution) to afford three fractions, A-C.

Concentration of fraction A $\left(R_{\mathrm{F}} \quad 0.4\right.$ in $3: 7 \mathrm{v} / \mathrm{v}$ ethyl acetate/hexane) afforded the starting compound 32 (54 mg, 16\% recovery) as a white solid, that was identical, in all respects, with an authentic sample.

Concentration of fraction $\mathrm{B}\left[R_{\mathrm{F}} 0.1(9)\right.$ in $3: 7 \mathrm{v} / \mathrm{v}$ ethyl acetate/hexane] gave the title compound 16 (118 mg, 42\% at $84 \%$ conversion) as a clear, colourless oil, $[\alpha]_{\mathrm{D}}+8(c$ 1.6, $\mathrm{CHCl}_{3}$ ) (Found: $\mathrm{M}^{+\bullet} 510.2619 . \mathrm{C}_{30} \mathrm{H}_{38} \mathrm{O}_{7}$ requires $\mathrm{M}^{+\bullet}$ 510.2618). $\delta_{\mathrm{H}}\left(\mathrm{CDCl}_{3}, 300 \mathrm{MHz}\right) 8.04(\mathrm{~m}, 2 \mathrm{H}), 7.58(\mathrm{~m}, 1 \mathrm{H})$, $7.45(\mathrm{~m}, 2 \mathrm{H}), 5.53(\mathrm{~d}, J 9.3,1 \mathrm{H}), 4.96(\mathrm{~s}, 1 \mathrm{H}), 3.68(\mathrm{~s}, 3 \mathrm{H})$, 2.72-2.56 (complex m, 2H), 2.31-2.23 (complex m, 4H), 2.11 $(\mathrm{m}, 2 \mathrm{H}), 1.96(\mathrm{~m}, 1 \mathrm{H}), 1.58(\mathrm{~m}, 2 \mathrm{H}), 1.32-1.20$ (complex m, $8 \mathrm{H})$, $1.18(\mathrm{~s}, 3 \mathrm{H}), 1.16(\mathrm{~s}, 3 \mathrm{H}), 0.85(\mathrm{~m}, 3 \mathrm{H}) . \delta_{\mathrm{C}}\left(\mathrm{CDCl}_{3}, 75 \mathrm{MHz}\right)$ 209.0 (C), 175.7 (C), 172.9 (C), 165.5 (C), 133.4 (CH), 129.9 $(\mathrm{CH}), 129.2(\mathrm{CH}), 128.6(\mathrm{C}), 84.0(\mathrm{CH}), 78.1(\mathrm{CH}), 61.8(\mathrm{CH})$, 52.3(3) $\left(\mathrm{CH}_{3}\right), 52.2(6)(\mathrm{C}), 50.9(\mathrm{C}), 41.2\left(\mathrm{CH}_{2}\right), 40.5(\mathrm{CH})$, $39.7(\mathrm{CH}), 39.1(\mathrm{CH}), 38.9(\mathrm{CH}), 34.3\left(\mathrm{CH}_{2}\right), 31.6\left(\mathrm{CH}_{2}\right), 29.0$ $\left(\mathrm{CH}_{2}\right), 28.8\left(\mathrm{CH}_{2}\right), 24.9\left(\mathrm{CH}_{2}\right), 22.5\left(\mathrm{CH}_{2}\right), 17.6\left(\mathrm{CH}_{3}\right), 14.3$ $\left(\mathrm{CH}_{3}\right), 14.0\left(\mathrm{CH}_{3}\right) \cdot v_{\max }(\mathrm{NaCl}) / \mathrm{cm}^{-1} 2920,2850,1734,1602$, $1452,1380,1266,1167,1107,1095,1069,1027,710 . \mathrm{m} / \mathrm{z}(\mathrm{EI}$, $70 \mathrm{eV}) 510\left(\mathrm{M}^{+\bullet}, 1 \%\right), 261(10), 244(20), 144$ (18), $105(100)$, 69 (35), 57 (34), 43 (33).

Concentration of fraction $\mathrm{C}\left[R_{\mathrm{F}} 0.1(5)\right.$ in $3: 7 \mathrm{v} / \mathrm{v}$ ethyl acetate/hexane] gave the title compound $17(112 \mathrm{mg}, 40 \%$ at $84 \%$ conversion) as a clear, colourless oil, $[\alpha]_{\mathrm{D}}-103(c$ 1.1, $\mathrm{CHCl}_{3}$ ) (Found: $\mathrm{M}^{+\bullet} 510.2618 . \mathrm{C}_{30} \mathrm{H}_{38} \mathrm{O}_{7}$ requires $\mathrm{M}^{+\bullet}$ 510.2618). $\delta_{\mathrm{H}}\left(\mathrm{CDCl}_{3}, 300 \mathrm{MHz}\right) 8.05(\mathrm{~m}, 2 \mathrm{H}), 7.61(\mathrm{~m}, 1 \mathrm{H})$, $7.48(\mathrm{~m}, 2 \mathrm{H}), 5.51(\mathrm{~d}, J 9.3,1 \mathrm{H}), 5.36(\mathrm{~d}, J 1.2,1 \mathrm{H}), 3.68(\mathrm{~s}, 3 \mathrm{H})$, $2.77(\mathrm{t}, J 8.5,1 \mathrm{H}), 2.58(\mathrm{~m}, 1 \mathrm{H}), 2.39(\mathrm{t}, J 5.3,1 \mathrm{H}), 2.34-2.16$ (complex m, 3H), 2.14-2.00 (complex m, 2H), $1.93(\mathrm{~m}, 1 \mathrm{H})$, $1.53(\mathrm{~m}, 2 \mathrm{H}), 1.38(\mathrm{~s}, 3 \mathrm{H}), 1.30-1.16$ (complex m, 8H), 1.16 
(s, 3H), $0.83(\mathrm{~m}, 3 \mathrm{H}) . \delta_{\mathrm{C}}\left(\mathrm{CDCl}_{3}, 75 \mathrm{MHz}\right) 205.3(\mathrm{C}), 175.6$ (C), $172.8(\mathrm{C}), 165.2(\mathrm{C}), 133.5(\mathrm{CH}), 129.9(\mathrm{CH}), 129.2(\mathrm{CH})$, $128.5(\mathrm{C}), 83.5(\mathrm{CH}), 78.0(\mathrm{CH}), 56.2(\mathrm{CH}), 52.3\left(\mathrm{CH}_{3}\right), 52.1$ (C), $49.5(\mathrm{C}), 41.0\left(\mathrm{CH}_{2}\right), 39.1(\mathrm{CH}), 35.6(\mathrm{CH}), 34.2\left(\mathrm{CH}_{2}\right)$, $33.7(\mathrm{CH}), 32.1(\mathrm{CH}), 31.6\left(\mathrm{CH}_{2}\right), 29.0\left(\mathrm{CH}_{2}\right), 28.8\left(\mathrm{CH}_{2}\right), 24.8$ $\left(\mathrm{CH}_{2}\right), 22.5\left(\mathrm{CH}_{2}\right), 19.7\left(\mathrm{CH}_{3}\right), 17.3\left(\mathrm{CH}_{3}\right), 14.0\left(\mathrm{CH}_{3}\right), v_{\max }$ $(\mathrm{NaCl}) / \mathrm{cm}^{-1} 2929,2854,1731,1602,1452,1383,1338,1314$, $1268,1247,1164,1111,1096,1071,710 . \mathrm{m} / \mathrm{z}(\mathrm{EI}, 70 \mathrm{eV}) 510$ $\left(\mathrm{M}^{+\bullet}, 12 \%\right), 262$ (16), 261 (19), 244 (10), 145 (9), 105 (100).

Method B: A deoxygenated solution of compound 15 $(417 \mathrm{mg}, 0.82 \mathrm{mmol})$ and acetophenone $(286 \mu \mathrm{L}, 2.46 \mathrm{mmol})$ in acetone $(350 \mathrm{~mL})$ was placed in a quartex immersion well photoreactor (Ace Glass Inc., $500 \mathrm{~mL}$ ) equipped with a Pyrex filter. This was subjected to irradiation with a Hanovia $450 \mathrm{~W}$ medium pressure quartz mercury-vapour lamp for $3 \mathrm{~h}$ and then cooled and concentrated under reduced pressure. The ensuing pale-yellow oil was subjected to flash chromatography (silica, $5 / 95 \rightarrow 3 / 7 \mathrm{v} / \mathrm{v}$ ethyl acetate/hexane gradient elution) to afford two fractions, $\mathrm{A}$ and $\mathrm{B}$.

Concentration of fraction A $\left[R_{\mathrm{F}} 0.1(9)\right.$ in $3 / 7$ ethyl acetate/hexane] afforded compound $\mathbf{1 6}(29 \mathrm{mg}, 7 \%)$ as a clear, colourless oil. This material was identical, in all respects, with that obtained by Method A as described immediately above.

Concentration of fraction $\mathrm{B}\left[R_{\mathrm{F}} 0.1(5)\right.$ in $3 / 7$ ethyl acetate/hexane] afforded compound $\mathbf{1 7}(346 \mathrm{mg}, 83 \%)$ as a clear, colourless oil. This material was identical, in all respects, with that obtained by Method A as described immediately above.

\section{Photochemically Promoted Epimerization of Compound 16. Formation of Isomer 17}

MethodA: A sample of compound $16(46 \mathrm{mg}, 0.09 \mathrm{mmol})$ was subjected to irradiation for $36 \mathrm{~h}$ under the conditions defined in Method A as detailed immediately above. Workup, followed by chromatographic purification afforded isomer 17 (44 mg, 96\%) that proved identical, in all respects, with an authentic sample.

Method B: A sample of compound $\mathbf{1 6}(59 \mathrm{mg}, 0.11 \mathrm{mmol})$ was subjected to irradiation for $0.5 \mathrm{~h}$ under the conditions defined in Method B as detailed immediately above. Workup, followed by chromatographic purification afforded isomer 17 (55 mg, 97\%) that proved identical, in all respects, with an authentic sample.

Methyl (2aR,2bR,2cR,4R,5R,5aR,5bR,5cS)-Decahydro4,5b-dimethyl-5-(octanoyloxy)-2-oxo- $1 \mathrm{H}$ -

cyclopenta[a]cyclopropa[cd]pentalene-

4-carboxylate (18)

Method A: A magnetically stirred solution of compound $17(56 \mathrm{mg}, 0.11 \mathrm{mmol})$ in THF/methanol $(2.1 \mathrm{~mL}$ of a $2 / 1 \mathrm{v} / \mathrm{v}$ mixture) was cooled to $-78^{\circ} \mathrm{C}$ and then treated, dropwise, with samarium(II) iodide $(2.4 \mathrm{~mL}$ of $0.1 \mathrm{M}$ solution in THF, $0.24 \mathrm{mmol}$ ) until a blue colour persisted for $\sim 10 \mathrm{~min}$. At this point the reaction mixture was treated with $\mathrm{K}_{2} \mathrm{CO}_{3}(10 \mathrm{~mL}$ of saturated aqueous solution) and after warming to $18^{\circ} \mathrm{C}$ the aqueous phase was separated and extracted with diethyl ether $(3 \times 2 \mathrm{~mL})$. The combined organic fractions were then washed with water $(1 \times 5 \mathrm{~mL})$ and brine $(1 \times 5 \mathrm{~mL})$ before being dried $\left(\mathrm{Na}_{2} \mathrm{SO}_{4}\right)$, filtered, and concentrated under reduced pressure to give the title compound $18(41 \mathrm{mg}, 96 \%)$ as a clear, colourless oil, $[\alpha]_{\mathrm{D}}$ $-21\left(c 1.4, \mathrm{CHCl}_{3}\right), R_{\mathrm{F}} 0.2$ (in $3 / 7$ ethyl acetate/hexane) (Found: $\mathrm{M}^{+\bullet}$ 390.2404. $\mathrm{C}_{23} \mathrm{H}_{34} \mathrm{O}_{5}$ requires $\mathrm{M}^{+\bullet}$ 390.2406). $\delta_{\mathrm{H}}\left(\mathrm{CDCl}_{3}\right.$, $300 \mathrm{MHz}) 5.44(\mathrm{~d}, J 9.6,1 \mathrm{H}), 3.66(\mathrm{~s}, 3 \mathrm{H}), 2.61(\mathrm{~m}, 1 \mathrm{H}), 2.47(\mathrm{~m}$, 1H), 2.38-2.19 (complex m, 5H), 2.08-2.00 (complex m, 3H), $1.79(\mathrm{~m}, 1 \mathrm{H}), 1.59(\mathrm{~m}, 2 \mathrm{H}), 1.28(\mathrm{~s}, 3 \mathrm{H}), 1.34-1.20$ (complex m,
$8 \mathrm{H}), 1.10(\mathrm{~s}, 3 \mathrm{H}), 0.86(\mathrm{~m}, 3 \mathrm{H}) . \delta_{\mathrm{C}}\left(\mathrm{CDCl}_{3}, 75 \mathrm{MHz}\right) 213.7(\mathrm{C})$ $175.9(\mathrm{C}), 172.8(\mathrm{C}), 78.5(\mathrm{CH}), 64.6(\mathrm{CH}), 57.1\left(\mathrm{CH}_{2}\right), 52.3$ $\left(\mathrm{CH}_{3}\right), 52.0(\mathrm{C}), 47.0(\mathrm{C}), 41.4\left(\mathrm{CH}_{2}\right), 39.8(\mathrm{CH}), 39.4(\mathrm{CH})$, $38.6(\mathrm{CH}), 38.3(\mathrm{CH}), 34.3\left(\mathrm{CH}_{2}\right), 31.6\left(\mathrm{CH}_{2}\right), 29.0\left(\mathrm{CH}_{2}\right), 28.9$ $\left(\mathrm{CH}_{2}\right), 24.9\left(\mathrm{CH}_{2}\right), 22.5\left(\mathrm{CH}_{2}\right), 21.3\left(\mathrm{CH}_{3}\right), 17.7\left(\mathrm{CH}_{3}\right), 14.0$ $\left(\mathrm{CH}_{3}\right) \cdot v_{\max }(\mathrm{NaCl}) / \mathrm{cm}^{-1} 2930,2857,1729,1461,1382,1285$, $1251,1230,1193,1167,1112,1087,1033,1005,972,935,874$, $813,769 . \mathrm{m} / \mathrm{z}(\mathrm{EI}, 70 \mathrm{eV}) 390\left(\mathrm{M}^{+\bullet}, 34 \%\right), 246(37), 187(56)$, 159 (27), 145 (70), 144 (100), 127 (28), 57 (57).

Method B: A sample of compound 16 (22 mg, $0.04 \mathrm{mmol})$ was subjected to the reaction with samarium(II) iodide at $-78^{\circ} \mathrm{C}$ under the conditions defined immediately above in Method A. Workup provided the title compound $\mathbf{1 8}(15 \mathrm{mg}, 95 \%)$ as a clear, colourless oil that proved identical, in all respects, with the material generated using Method A.

Method $C$ : A sample of a $\sim 1: 3$ mixture of compounds 16 and $17(784 \mathrm{mg}, 1.53 \mathrm{mmol})$ was subjected to the reaction with samarium(II) iodide at $-78^{\circ} \mathrm{C}$ under the conditions defined in Method A immediately above. Workup provided the title compound $18(562 \mathrm{mg}, 96 \%)$ as a clear, colourless oil that proved identical, in all respects, with the material generated by Methods $\mathrm{A}$ and $\mathrm{B}$.

\section{Methyl (2R,3R,3aR,3bR,6aS,7aS)-Decahydro-}

2,3b-dimethyl-3-(octanoyloxy)-5-oxo- $1 \mathrm{H}$ -

cyclopenta[a]pentalene-2-carboxylate (19)

A magnetically stirred solution of cyclopropane 18 (722 mg, $1.84 \mathrm{mmol})$ and AIBN (6 mg, $0.02 \mathrm{mmol})$ in benzene $(58 \mathrm{~mL})$ was treated at $18^{\circ} \mathrm{C}$ with tri- $n$-butyltin hydride $(995 \mu \mathrm{L}$, $3.70 \mathrm{mmol}$ ). The ensuing mixture was heated at reflux for $1.5 \mathrm{~h}$ and then cooled to $18^{\circ} \mathrm{C}$ and treated with further aliquots of AIBN $(6 \mathrm{mg}, 0.02 \mathrm{mmol})$ and tri- $n$-butyltin hydride $(995 \mu \mathrm{L}$, $3.70 \mathrm{mmol})$. The reaction mixture was then heated at reflux for a further $1.5 \mathrm{~h}$. This process was repeated once more so that a total of six equivalents of tri- $n$-butyltin hydride were added to the original reaction mixture and a total reflux time of $4.5 \mathrm{~h}$ had been employed. The cooled reaction mixture was then concentrated under reduced pressure and the light-yellow oil thus obtained was subjected to flash chromatography ( silica, $0 / 1 \rightarrow 1 / 4 \mathrm{v} / \mathrm{v}$ ethyl acetate/hexane gradient elution) affording two fractions, A and $\mathrm{B}$.

Concentration of fraction A $\left(R_{\mathrm{F}} \quad 0.2\right.$ in $3 / 7 \mathrm{v} / \mathrm{v}$ ethyl acetate/hexane) afforded the starting compound 18 (34 mg, 5\% recovery) as a clear, colourless oil that was identical, in all respects, with an authentic sample.

Concentration of fraction $\mathrm{B}\left(R_{\mathrm{F}} 0.3\right.$ in $3 / 7 \mathrm{v} / \mathrm{v}$ ethyl acetate/hexane) gave a white solid that was recrystallized (cyclohexene) to give the title compound $19(574 \mathrm{mg}, 83 \%$ at $95 \%$ conversion) as white crystals, $\mathrm{mp} 50-54^{\circ} \mathrm{C},[\alpha]_{\mathrm{D}}-75\left(\mathrm{c} 0.6, \mathrm{CHCl}_{3}\right)$ (Found: $\mathrm{M}^{+\bullet} 392.2565 . \mathrm{C}_{23} \mathrm{H}_{36} \mathrm{O}_{5}$ requires $\mathrm{M}^{+\bullet} 392.2563$ ). $\delta_{\mathrm{H}}$ $\left(\mathrm{CDCl}_{3}, 300 \mathrm{MHz}\right) 5.39(\mathrm{~d}, J 9.0,1 \mathrm{H}), 3.66(\mathrm{~s}, 3 \mathrm{H}), 2.81(\mathrm{~m}, 1 \mathrm{H})$, 2.59-2.39 (complex m, 3H), 2.28 (m, 2H), 2.19-2.07 (complex $\mathrm{m}, 3 \mathrm{H}), 1.96(\mathrm{~m}, 2 \mathrm{H}), 1.80(\mathrm{~m}, 1 \mathrm{H}), 1.66-1.47$ (complex m, 3H), 1.34-1.22 (complex m, 8H), 1.17 (s, 3H), $1.06(\mathrm{~s}, 3 \mathrm{H}), 0.87(\mathrm{~m}$, $3 \mathrm{H}) . \delta_{\mathrm{C}}\left(\mathrm{CDCl}_{3}, 75 \mathrm{MHz}\right) 219.3(\mathrm{C}), 175.7(\mathrm{C}), 172.8(\mathrm{C}), 79.1$ $(\mathrm{CH}), 55.5(\mathrm{CH}), 52.3(\mathrm{C}), 52.1\left(\mathrm{CH}_{3}\right), 51.0\left(\mathrm{CH}_{2}\right), 48.6(\mathrm{C})$, $45.1(\mathrm{CH}), 42.7\left(\mathrm{CH}_{2}\right), 41.9\left(\mathrm{CH}_{2}\right), 38.6\left(\mathrm{CH}_{2}\right), 37.6(\mathrm{CH}), 34.3$ $\left(\mathrm{CH}_{2}\right), 31.6\left(\mathrm{CH}_{2}\right), 29.0\left(\mathrm{CH}_{2}\right), 28.9\left(\mathrm{CH}_{2}\right), 25.0\left(\mathrm{CH}_{2}\right), 22.6$ $\left(\mathrm{CH}_{2}\right), 21.3\left(\mathrm{CH}_{3}\right), 15.8\left(\mathrm{CH}_{3}\right), 14.1\left(\mathrm{CH}_{3}\right) \cdot v_{\max }(\mathrm{NaCl}) / \mathrm{cm}^{-1}$ 2929, 2857, 1740, 1462, 1434, 1407, 1381, 1350, 1260, 1169, 1100, 1018, 802, 725. m/z (EI, $70 \mathrm{eV}) 392\left(\mathrm{M}^{+\bullet}, 5 \%\right), 248$ (20), 189 (100), 180 (16), 127 (79), 109 (18), 93 (16), 57 (71), $43(20)$. 
Methyl (2R,3R,3aR,3bS,7aS)-2,3,3a,3b,4,5,7,7aOctahydro-2,3b-dimethyl-3-(octanoyloxy)-5-oxo$1 \mathrm{H}$-cyclopenta[a]pentalene-2-carboxylate (20)

A magnetically stirred solution of ketone 19 (70 mg, $0.18 \mathrm{mmol})$ in toluene-dimethyl sulfoxide (DMSO) $(1.8 \mathrm{~mL}$ of a $2 / 1 \mathrm{v} / \mathrm{v}$ mixture) was treated with $p-\mathrm{TsOH} \cdot \mathrm{H}_{2} \mathrm{O}(5 \mathrm{mg}$, $0.06 \mathrm{mmol})$ and $\mathrm{IBX}^{[21]}(196 \mathrm{mg}, 0.70 \mathrm{mmol})$. The resulting mixture was heated at $55^{\circ} \mathrm{C}$ for $96 \mathrm{~h}$ and then cooled and diluted with diethyl ether $(4 \mathrm{~mL})$. The separated organic phase was washed with $\mathrm{NaHCO}_{3}(2 \times 2 \mathrm{~mL}$ of a $5 \% \mathrm{w} / \mathrm{v}$ aqueous solution), water $(2 \times 3 \mathrm{~mL})$, and brine $(1 \times 5 \mathrm{~mL})$, and then dried $\left(\mathrm{Na}_{2} \mathrm{SO}_{4}\right)$, filtered, and concentrated under reduced pressure to give a light-yellow oil. Subjection of this material to flash chromatography (silica, 1/4 v/v ethyl acetate/hexane elution) afforded, after concentration of the appropriate fractions $\left(R_{\mathrm{F}}\right.$ $0.2 \mathrm{in} 3 / 7 \mathrm{v} / \mathrm{v}$ ethyl acetate/hexane), the title enone $20(56 \mathrm{mg}$, $81 \%)$ as a clear, colourless oil, $[\alpha]_{\mathrm{D}}-65\left(c 0.7, \mathrm{CHCl}_{3}\right)$ (Found: $\mathrm{M}^{+\bullet} 390.2410 . \mathrm{C}_{23} \mathrm{H}_{34} \mathrm{O}_{5}$ requires $\left.\mathrm{M}^{+\bullet} 390.2406\right) . \delta_{\mathrm{H}}\left(\mathrm{CDCl}_{3}\right.$, $300 \mathrm{MHz}) 5.71(\mathrm{~d}, J 1.5,1 \mathrm{H}), 5.48(\mathrm{~d}, J 6.6,1 \mathrm{H}), 3.69(\mathrm{~s}, 3 \mathrm{H})$, 3.00-2.78 (complex m, 2H), 2.43-1.93 (complex m, 8H), 1.59 $(\mathrm{m}, 2 \mathrm{H}), 1.35(\mathrm{~s}, 3 \mathrm{H}), 1.28(\mathrm{~s}, 3 \mathrm{H}), 1.34-1.21$ (complex m, 8H), $0.87(\mathrm{~m}, 3 \mathrm{H}) . \delta_{\mathrm{C}}\left(\mathrm{CDCl}_{3}, 75 \mathrm{MHz}\right) 210.2(\mathrm{C}), 193.3(\mathrm{C}), 175.4$ (C), $173.2(\mathrm{C}), 122.9(\mathrm{CH}), 78.0(\mathrm{CH}), 55.7(\mathrm{CH}), 55.0(\mathrm{C})$, $52.6\left(\mathrm{CH}_{2}\right), 52.3\left(\mathrm{CH}_{3}\right), 49.2(\mathrm{C}), 43.7\left(\mathrm{CH}_{2}\right), 41.4(\mathrm{CH}), 34.2$ $\left(\mathrm{CH}_{2}\right), 32.1\left(\mathrm{CH}_{2}\right), 31.6\left(\mathrm{CH}_{2}\right), 29.0\left(\mathrm{CH}_{2}\right), 28.9\left(\mathrm{CH}_{2}\right), 25.0$ $\left(\mathrm{CH}_{2}\right), 24.5\left(\mathrm{CH}_{3}\right), 22.6\left(\mathrm{CH}_{2}\right), 17.0\left(\mathrm{CH}_{3}\right), 14.0\left(\mathrm{CH}_{3}\right) . v_{\max }$ $(\mathrm{NaCl}) / \mathrm{cm}^{-1} 2922,2851,1736,1710,1638,1465,1383,1256$, 1222, 1165, 1106, 667. $\mathrm{m} / \mathrm{z}(\mathrm{EI}, 70 \mathrm{eV}) 390\left(\mathrm{M}^{+\bullet}, 24 \%\right), 359$ (5), 358 (8), 264 (26), 246 (100), 187 (50), 186 (52), 127 (29), 57 (70), 43 (34).

Methyl (2R,3R,3aR,3bS,7aS)-2,3,3a,3b,4,5,7,7aOctahydro-2,3b-dimethyl-4-methylene-3-

(octanoyloxy)-5-oxo-1H-cyclopentala]pentalene2-carboxylate (22)

Step (i): A magnetically stirred solution of enone $20(57 \mathrm{mg}$, $0.15 \mathrm{mmol})$ in THF $(2 \mathrm{~mL})$ maintained at $-78^{\circ} \mathrm{C}$ was treated dropwise with LiHMDS $(170 \mu \mathrm{L}$ of a $1.0 \mathrm{M}$ solution in THF, $0.17 \mathrm{mmol}$ ) and the resulting mixture stirred at this temperature for $1 \mathrm{~h}$. After this time Eschenmoser's salt $(81 \mathrm{mg}, 0.44 \mathrm{mmol}$, Aldrich Chemical Co.) was added, in one portion, to the reaction mixture that was then allowed to warm to $18^{\circ} \mathrm{C}$ and stirred at this temperature for $16 \mathrm{~h}$. The reaction mixture was then quenched with $\mathrm{HCl}(10 \mathrm{~mL}$ of a $3 \mathrm{M}$ aqueous solution) and after $5 \mathrm{~min}$ the aqueous phase was separated and extracted with diethyl ether $(3 \times 10 \mathrm{~mL})$. The combined organic phases were washed with $\mathrm{NaHCO}_{3}(1 \times 25 \mathrm{~mL}$ of saturated aqueous solution $)$ and brine $(1 \times 25 \mathrm{~mL})$, and then dried $\left(\mathrm{Na}_{2} \mathrm{SO}_{4}\right)$, filtered, and concentrated under reduced pressure to afford the starting enone 20 (20 mg, 35\% recovery) as a clear, colourless oil. This material was identical, in all respects, with an authentic sample.

The aqueous layers obtained as described above were combined and basified to $\mathrm{pH} 14$ using $\mathrm{NaOH}$ (4 M aqueous solution) and then extracted with dichloromethane $(3 \times 10 \mathrm{~mL})$. The combined organic fractions were dried $\left(\mathrm{Na}_{2} \mathrm{SO}_{4}\right)$, filtered, and concentrated under reduced pressure to give tertiary amine 21 (32 mg, $75 \%$ at $65 \%$ conversion) as a yellow oil and as a single diastereoisomer of undetermined configuration at $\mathrm{C} 4$ (Found: $\mathrm{M}^{+\bullet}$ 447.2986. $\mathrm{C}_{26} \mathrm{H}_{41} \mathrm{NO}_{5}$ requires $\mathrm{M}^{+\bullet}$ 447.2985). $\delta_{\mathrm{H}}\left(\mathrm{CDCl}_{3}, 300 \mathrm{MHz}\right) 5.66(\mathrm{~d}, J 1.8,1 \mathrm{H}), 5.63(\mathrm{~d}, J 6.9,1 \mathrm{H})$, 3.69 (s, 3H), 2.98-2.65 (complex m, 2H), 2.42-1.96 (complex $\mathrm{m}, 7 \mathrm{H}), 2.16(\mathrm{~s}, 6 \mathrm{H}), 1.62(\mathrm{~m}, 2 \mathrm{H}), 1.38(\mathrm{~s}, 3 \mathrm{H}), 1.29(\mathrm{~s}, 3 \mathrm{H})$,
1.34-1.18 (complex m, 10H), $0.88(\mathrm{~m}, 3 \mathrm{H}) . v_{\max }(\mathrm{NaCl}) / \mathrm{cm}^{-1}$ 2924, 2853, 1736, 1703, 1640, 1463, 1381, 1258, 1158, 1104. $\mathrm{m} / \mathrm{z}(\mathrm{EI}, 70 \mathrm{eV}) 447\left(\mathrm{M}^{+\bullet}, 100 \%\right), 416(10), 402$ (24), $276(36)$, 258 (26), 244 (23), 216 (22), 199 (28), 198 (35), 127 (37).

This material was subjected, without further characterization, to step (ii) of the reaction sequence as described immediately below.

Step (ii): A magnetically stirred solution of amine 21 (35 mg, $0.08 \mathrm{mmol})$ in diethyl ether/dichloromethane $(3.5 \mathrm{~mL}$ of a $3 / 1$ mixture) was treated with iodomethane $(59 \mu \mathrm{L}, 0.95 \mathrm{mmol})$ and the resulting solution was stirred at $18^{\circ} \mathrm{C}$ for $16 \mathrm{~h}$ and then concentrated under reduced pressure. The ensuing yellow oil, presumed to contain the methiodide salt of amine 21, was dissolved in dichloromethane $(5 \mathrm{~mL})$ and the solution so obtained treated with basic alumina ( $\sim 300 \mathrm{mg}$ of $0.063-0.200$ mesh and grade 1 activity material). The resulting suspension was stirred magnetically at $18^{\circ} \mathrm{C}$ for $0.5 \mathrm{~h}$ and then concentrated under reduced pressure and the solid mass thus obtained was dried under reduced pressure $(\sim 6 \mathrm{mmHg})$. The resulting solid was loaded onto the top of a flash chromatography column composed ofTLC-grade alumina and this was eluted with dichloromethane. Concentration of the relevant fractions $\left(R_{\mathrm{F}} 0.3\right.$ in $3 / 7 \mathrm{v} / \mathrm{v}$ ethyl acetate/hexane) then afforded the title dienone $22(25 \mathrm{mg}, 80 \%)$ as a clear, colourless oil, $[\alpha]_{\mathrm{D}}-54\left(c 0.9, \mathrm{CHCl}_{3}\right)$ (Found: $\mathrm{M}^{+\bullet}$ 402.2408. $\mathrm{C}_{24} \mathrm{H}_{34} \mathrm{O}_{5}$ requires $\mathrm{M}^{+\bullet}$ 402.2406). $\delta_{\mathrm{H}}\left(\mathrm{CDCl}_{3}\right.$, $300 \mathrm{MHz}) 5.93(\mathrm{~d}, J 1.5,1 \mathrm{H}), 5.90(\mathrm{~s}, 1 \mathrm{H}), 5.76(\mathrm{~d}, J 7.5,1 \mathrm{H})$, $5.15(\mathrm{~s}, 1 \mathrm{H}), 3.70(\mathrm{~s}, 3 \mathrm{H}), 2.98-2.80$ (complex m, 2H), 2.45-2.38 (complex m, 4H), 2.09 (m, 2H), $1.62(\mathrm{~m}, 2 \mathrm{H}), 1.38(\mathrm{~s}, 3 \mathrm{H}), 1.34$ 1.23 (complex m, 8H), $1.25(\mathrm{~s}, 3 \mathrm{H}), 0.87(\mathrm{~m}, 3 \mathrm{H}) . \delta_{\mathrm{C}}\left(\mathrm{CDCl}_{3}\right.$, $75 \mathrm{MHz}) 197.1$ (C), 187.5 (C), 175.3 (C), 173.0 (C), 153.0 (C), $123.9(\mathrm{CH}), 114.4\left(\mathrm{CH}_{2}\right), 77.3(\mathrm{CH}), 55.0(\mathrm{C}), 52.3\left(\mathrm{CH}_{3}\right), 52.2$ $(\mathrm{CH}), 51.1(\mathrm{C}), 43.3\left(\mathrm{CH}_{2}\right), 41.3(\mathrm{CH}), 34.3\left(\mathrm{CH}_{2}\right), 32.3\left(\mathrm{CH}_{2}\right)$, $31.6\left(\mathrm{CH}_{2}\right), 29.1\left(\mathrm{CH}_{2}\right), 28.9\left(\mathrm{CH}_{2}\right), 25.0\left(\mathrm{CH}_{2}\right), 23.8\left(\mathrm{CH}_{3}\right)$, $22.6\left(\mathrm{CH}_{2}\right), 16.7\left(\mathrm{CH}_{3}\right), 14.1\left(\mathrm{CH}_{3}\right) . v_{\max }(\mathrm{NaCl}) / \mathrm{cm}^{-1} 2924$, 2853, 1736, 1704, 1626, 1456, 1262, 1156, 1100, 801. $\mathrm{m} / \mathrm{z}$ (EI, $70 \mathrm{eV}) 402\left(\mathrm{M}^{+\bullet}, 60 \%\right), 370(31), 342(10), 276(74), 258(61)$, 244 (36), 216 (41), 199 (50), 198 (62), 155 (31), 127 (45), 57 (100), 43 (46).

\section{(2R,3R,3aR,3bS, 7aS)-2,3,3a,3b, 4, 5, 7,7a-Octahydro-} 2,3b-dimethyl-4-methylene-3-(octanoyloxy)-5-oxo-1 $\mathrm{H}$ cyclopenta[a]pentalene-2-carboxylic Acid (23)

A magnetically stirred solution of ester $22(30 \mathrm{mg}$, $0.07 \mathrm{mmol})$ in tetrahydrothiophene $(0.75 \mathrm{~mL})$ maintained at $18^{\circ} \mathrm{C}$ was treated, in one portion, with aluminium tribromide (120 mg, $0.42 \mathrm{mmol})$. The ensuing mixture was stirred at $18^{\circ} \mathrm{C}$ for $0.5 \mathrm{~h}$ and then treated with dichloromethane $(2 \mathrm{~mL})$ and $\mathrm{HCl}$ ( $3 \mathrm{~mL}$ of a $10 \% \mathrm{w} / \mathrm{v}$ aqueous solution). The separated aqueous phase was extracted with dichloromethane $(3 \times 4 \mathrm{~mL})$ and the combined organic phases were then dried $\left(\mathrm{Na}_{2} \mathrm{SO}_{4}\right)$, filtered, and concentrated under reduced pressure to yield a yellow oil. Subjection of this material to flash chromatography (silica, $0 / 1 \rightarrow 1 / 20 \mathrm{v} / \mathrm{v}$ acetic acid/dichloromethane gradient elution) afforded two fractions, $\mathrm{A}$ and $\mathrm{B}$.

Concentration of fraction A $\left(R_{\mathrm{F}} 0.3\right.$ in $3 / 7 \mathrm{v} / \mathrm{v}$ ethyl acetate/hexane) afforded the starting ester 21 ( $5 \mathrm{mg}, 17 \%$ recovery) as a clear colourless oil. This material was identical, in all respects, with an authentic sample.

Concentration of fraction B $\left(R_{\mathrm{F}} 0.3\right.$ in $50 / 50 / 1 \mathrm{v} / \mathrm{v} / \mathrm{v}$ ethyl acetate/hexane/acetic acid) afforded the title acid $22(24 \mathrm{mg}$, $89 \%$ at $83 \%$ conversion) as a clear, colourless oil, $[\alpha]_{\mathrm{D}}-66(c$ $0.3, \mathrm{CHCl}_{3}$ ) (Found: $\mathrm{M}^{+\bullet} 388.2249 . \mathrm{C}_{23} \mathrm{H}_{32} \mathrm{O}_{5}$ requires $\mathrm{M}^{+\bullet}$ 388.2250). $\delta_{\mathrm{H}}\left(\mathrm{CDCl}_{3}, 300 \mathrm{MHz}\right) 5.95(\mathrm{~d}, J 1.2,1 \mathrm{H}), 5.91(\mathrm{~s}$, 
1H), 5.84 (d, J 7.2, 1H), 5.19 (s, 1H), 3.00-2.81 (complex m, 2H), 2.44-2.29 (complex m, 4H), 2.21-2.04 (complex m, 2H), $1.63(\mathrm{~m}, 2 \mathrm{H}), 1.42(\mathrm{~s}, 3 \mathrm{H}), 1.35-1.20$ (complex m, 8H), 1.29 $(\mathrm{s}, 3 \mathrm{H}), 0.88(\mathrm{~m}, 3 \mathrm{H})$ (signal due to carboxylic acid proton not observed). $\delta_{\mathrm{C}}\left(\mathrm{CDCl}_{3}, 75 \mathrm{MHz}\right) 197.1(\mathrm{C}), 187.6(\mathrm{C}), 180.3(\mathrm{C})$, $173.3(\mathrm{C}), 152.8(\mathrm{C}), 123.9(\mathrm{CH}), 114.6\left(\mathrm{CH}_{2}\right), 77.2(\mathrm{CH}), 52.6$ $(\mathrm{CH}), 51.2(\mathrm{C}), 43.6\left(\mathrm{CH}_{2}\right), 41.5(\mathrm{C}), 34.3\left(\mathrm{CH}_{2}\right), 32.2(\mathrm{CH}$ and $\left.\mathrm{CH}_{2}\right), 31.6\left(\mathrm{CH}_{2}\right), 29.1\left(\mathrm{CH}_{2}\right), 28.9\left(\mathrm{CH}_{2}\right), 25.0\left(\mathrm{CH}_{2}\right), 23.7$ $\left(\mathrm{CH}_{3}\right), 22.6\left(\mathrm{CH}_{2}\right), 16.7\left(\mathrm{CH}_{3}\right), 14.1\left(\mathrm{CH}_{3}\right) \cdot v_{\max }(\mathrm{NaCl}) / \mathrm{cm}^{-1}$ 2957, 2927, 2855, 1736, 1703, 1650, 1623, 1466, 1407, 1381, $1260,1160,1102,1004,943,863,747,661 . \mathrm{m} / z(E I, 70 \mathrm{eV}) 388$ $\left(\mathrm{M}^{+\bullet}, 54 \%\right), 370$ (25), 262 (54), 244 (76), 216 (61), 199 (43), 198 (40), 127 (40), 95 (25), 57 (100), 43 (47).

\section{(1aS,3aR,3bR,4R,5R,6aR,7aS)-Decahydro-}

3a,5-dimethyl-3-methylene-4-(octanoyloxy)-

2-oxocyclopenta[4,5]pentaleno-[1,6a-b]oxirene-

5-carboxylic Acid [(-)-Phellodonic Acid (1)]

A magnetically stirred solution of dienone acid $22(10 \mathrm{mg}$, $0.02(6) \mathrm{mmol})$ in methanol-water $(1.7 \mathrm{~mL}$ of a $1 / 1 \mathrm{v} / \mathrm{v} \mathrm{mix}-$ ture) was cooled to $0^{\circ} \mathrm{C}$ and then treated with $\mathrm{NaHCO}_{3}$ (44 mg, $0.52 \mathrm{mmol}$ ) and hydrogen peroxide [26 $\mu \mathrm{L}$ of a $30 \%$ $\mathrm{w} / \mathrm{v}$ aqueous solution, $0.07(8) \mathrm{mmol}$. The ensuing mixture was warmed to $18^{\circ} \mathrm{C}$, stirred at this temperature for $1.25 \mathrm{~h}$, and then poured into a mixture of ethyl acetate $(2 \mathrm{~mL})$ and $\mathrm{NH}_{4} \mathrm{Cl}(1.5 \mathrm{~mL}$ of a saturated aqueous solution). The separated aqueous layer was extracted with ethyl acetate $(2 \times 3 \mathrm{~mL})$ and the combined organic phases were then dried $\left(\mathrm{MgSO}_{4}\right)$, filtered, and concentrated under reduced pressure to give a light-yellow oil. Subjection of this material to flash chromatography (silica, 50/50/1 v/v/v ethyl acetate/hexane/acetic acid elution) afforded, after concentration of the appropriate fractions $\left(R_{\mathrm{F}} 0.5\right.$ in $50 / 50 / 1 \mathrm{v} / \mathrm{v} / \mathrm{v}$ ethyl acetate/hexane/acetic acid), phellodonic acid (1) $(5 \mathrm{mg}, 48 \%)$ as a clear, colourless oil, $[\alpha]_{\mathrm{D}}-120\left(c \quad 0.2, \mathrm{CHCl}_{3}\right)$ [Found: $(\mathrm{M}+\mathrm{H})^{+} 405.2291$ and $(\mathrm{M}+\mathrm{Na})^{+}$427.2107. $\mathrm{C}_{23} \mathrm{H}_{32} \mathrm{O}_{6}$ requires $(\mathrm{M}+\mathrm{H})^{+} 405.2277$ and $\left.(\mathrm{M}+\mathrm{Na})^{+} 427.2097\right] . \delta_{\mathrm{H}}\left(\mathrm{CDCl}_{3}, 800 \mathrm{MHz}\right)$ see Table 3 . $\delta_{\mathrm{C}}\left(\mathrm{C}_{6} \mathrm{D}_{6}, 125 \mathrm{MHz}\right)$ see Table $2 . v_{\max }(\mathrm{NaCl}) / \mathrm{cm}^{-1} 3507,2925$, 2854, 1732, 1638, 1464, 1381, 1255, 1167, 1101, 1033, 1012. $\mathrm{m} / \mathrm{z}$ (EI, $70 \mathrm{eV}$ ) see Table 1.

\section{X-Ray Crystallographic Studies \\ Crystal Data}

Compound 11. $\mathrm{C}_{18} \mathrm{H}_{26} \mathrm{O}_{5} \cdot \mathrm{CH}_{3} \mathrm{OH}, M 354.44, T 200(1) \mathrm{K}$, orthorhombic, space group $P 2{ }_{1}{ }_{2}{ }_{1}{ }_{1}, Z 4, a 8.3800(1), b$ 8.4423(2), c 26.4809(6) $\AA, V 1873.43(6) \AA^{3}, D_{\mathrm{x}} 1.257 \mathrm{~g} \mathrm{~cm}^{-3}$, 3111 unique data $\left(2 \theta_{\max } 60.0^{\circ}\right), 2252$ with $I>2.0 \sigma(I), R 0.033$; $R_{w}$ 0.097, $S 0.91$.

Compound 19. $\mathrm{C}_{23} \mathrm{H}_{36} \mathrm{O}_{5} \cdot 0.5\left(\mathrm{C}_{6} \mathrm{H}_{12}\right), M 434.62, T 200(1) \mathrm{K}$, orthorhombic, space group $P 2{ }_{1} 2_{1} 2_{1}, Z 4, a$ 6.1374(8), $b$ 9.6316(13), c 49.264(7) $\AA, V 2912.2(7) \AA^{3}, D_{\mathrm{x}} 0.991 \mathrm{~g} \mathrm{~cm}^{-3}$, 2337 unique data $\left(2 \theta_{\max } 46.4^{\circ}\right), 1348$ with $I>2.0 \sigma(I), R 0.109$; $R_{w}$ 0.097, $S$ 1.14.

\section{Structure Determination}

Images were measured on a Nonius Kappa CCD diffractometer $(\mathrm{MoK} \alpha$, graphite monochromator, $\lambda 0.71073 \AA)$ and data extracted using the DENZO package. ${ }^{[27]}$ Structure solution was by direct methods (SIR92). ${ }^{[2]}$ The structure of compounds 11 and 19 were refined using the CRYSTALS program package. ${ }^{[29]}$ Atomic coordinates, bond lengths and angles, and displacement parameters have been deposited at the Cambridge Crystallographic Data Centre (CCDC numbers 667993 and 667994, respectively). These data can be obtained free-ofcharge from www.ccdc.cam.ac.uk/data_request/cif, by emailing data_request@ccdc.cam.ac.uk, or by contacting the Cambridge Crystallographic Data Centre, 12 Union Road, Cambridge CB2 1EZ, UK; fax: +44 1223336033.

\section{Acknowledgements}

We thank the Institute of Advanced Studies and the Australian Research Council for generous financial support. Professor Wolfgang Steglich (LMU, Munich) is warmly acknowledged for providing copies of the original ${ }^{1} \mathrm{H}$ and ${ }^{13} \mathrm{C}$ NMR spectra of the naturally-derived phellodonic acid (1).

\section{References}

[1] M. Stadler, T. Anke, J. Dasenbrock, W. Steglich, Z. Naturforsch. C: J. Biosci. 1993, 48, 545.

[2] G. Mellows, P. G. Mantle, T. C. Feline, D. J. Williams, Phytochemistry 1973, 12, 2717. doi:10.1016/0031-9422(73)85086-1

[3] J. Kupka, T. Anke, B.-M. Giannetti, W. Steglich, Arch. Microbiol. 1981, 130, 223. doi:10.1007/BF00459523

[4] B. M. Giannetti, B. Steffan, W. Steglich, J. Kupka, T. Anke, Tetrahedron 1986, 42, 3587. doi:10.1016/S0040-4020(01)87325-7

[5] D. Abate, W.-R. Abraham, J. Antibiotics 1994, 47, 1348.

[6] S. Nozoe, J. Furukawa, U. Sankawa, S. Shibata, Tetrahedron Lett. 1976, 17, 195. doi:10.1016/0040-4039(76)80013-5

[7] S. Takahashi, H. Naganawa, H. Iinuma, T. Takita, K. Maeda, H. Umezawa, Tetrahedron Lett. 1971, 12, 1955. doi:10.1016/S00404039(01)96751-6

[8] M. G. Banwell, K. A. B. Austin, A. C. Willis, Tetrahedron 2007, 63, 6388. doi:10.1016/J.TET.2007.03.073

[9] For reviews on the production and general synthetic utility of these types of metabolites see

(a) T. Hudlicky, D. Gonzalez, D. T. Gibson, Aldrichim. Acta 1999 , 32,35 .

(b) M. G. Banwell, A. J. Edwards, G. J. Harfoot, K. A. Jolliffe, M. D. McLeod, K. J. McRae, S. G. Stewart, M. Vögtle, Pure Appl. Chem. 2003, 75, 223

(c) R. A. Johnson, Org. React. 2004, 63, 117

[10] See, for example: M. Demuth, P. Ritterskamp, E. Weigt, K. Schaffner, J. Am. Chem. Soc. 1986, 108, 4149, and references cited therein.

[11] (a) V. Singh, D. K. Tosh, S. M. Mobin, Tetrahedron Lett. 2004, 45, 1729. doi:10.1016/J.TETLET.2003.12.095

(b) C.-C. Liao, Pure Appl. Chem. 2005, 77, 1221. doi:10.1351/ PAC200577071221

[12] M. G. Banwell, J. R. Dupuche, R. W. Gable, Aust. J. Chem. 1996, 49, 639.

[13] C. O. Kappe, Angew. Chem. Int. Ed. 2004, 43, 6250. doi:10.1002/ ANIE.200400655

[14] L. N. Mander, S. P. Sethi, Tetrahedron Lett. 1983, 24, 5425. doi:10.1016/S0040-4039(00)87886-7

[15] L. Kürti, B. Czakó, Strategic Applications of Named Reactions in Organic Synthesis 2005, pp. 268-269 (Elsevier Academic Press: Burlington, MA), and references therein.

[16] M. G. Banwell, V. S. Bridges, J. R. Dupuche, S. L. Richards, J. M. Walter, J. Org. Chem. 1994, 59, 6338. doi:10.1021/ JO00100A040

[17] V. Singh, in CRC Handbook of Organic Photochemistry and Photobiology, 2nd edn (Eds W. M. Horspool, F. Lenci) 2004, pp. 78/1-78/34 (CRC Press LLC: Boca Raton, FL)

[18] See, for example: J. Jauch, Tetrahedron 1994, 50, 12903. doi:10.1016/S0040-4020(01)81209-6

[19] L. M. Jackman, S. Sternhell, Applications of Nuclear Magnetic Resonance Spectroscopy in Organic Chemistry, 2nd edn 1969, pp. 238-241 (Pergamon Press: Oxford)

[20] G. A. Molander, Org. React. 1994, 46, 211. 
[21] K. C. Nicolaou, T. Montagnon, P. S. Baran, Angew. Chem. Int. Ed. 2002, 41, 993, and references cited therein. doi:10.1002/15213773(20020315)41:6<993::AID-ANIE993>3.0.CO;2-U

[22] J. Schreiber, H. Maag, N. Hashimoto, A. Eschenmoser, Angew. Chem. Int. Ed. Engl. 1971, 10, 330. doi:10.1002/ANIE.197103301

[23] For reviews on this so-called Eschenmoser methylenation sequence see: L. Kürti, B. Czakó, Strategic Applications of Named Reactions in Organic Synthesis 2005, pp. 154-155 (Elsevier Academic Press: Burlington, MA), and references therein.

[24] A. E. Greene, M. J. Luche, A. A. Serra, J. Org. Chem. 1985, 50, 3957. doi:10.1021/JO00221A001

[25] D. R. Boyd, N. D. Sharma, S. A. Barr, H. Dalton, J. Chima, G. Whited, R. Seemayer, J. Am. Chem. Soc. 1994, 116, 1147. doi:10.1021/JA00082A053
[26] W. C. Still, M. Kahn, A. Mitra, J. Org. Chem. 1978, 43, 2923. doi:10.1021/JO00408A041

[27] DENZO-SMN Z. Otwinowski, W. Minor, Processing of X-ray diffraction data collected in oscillation mode, in Methods in Enzymology, Volume 276: Macromolecular Crystallography, Part A (Eds C. W. Carter, Jr, R. M. Sweet) 1997, pp. 307-326 (Academic Press: New York, NY).

[28] A. Altomare, G. Cascarano, C. Giacovazzo, A. Guagliardi, M. C. Burla, G. Polidori, M. Camalli, J. Appl. Crystallogr. 1994, 27, 435. doi:10.1107/S002188989400021X

[29] P. W. Betteridge, J. R. Carruthers, R. I. Cooper, K. Prout, D. J. Watkin, J. Appl. Crystallogr. 2003, 36, 1487. doi:10.1107/S0021889803021800 